\title{
THE TRADE SYSTEM AND CLIMATE AC- TION: WAYS FORWARD UNDER THE PARIS AGREEMENT
}

\author{
Susanne Droege, Harro van Asselt, Kasturi Das and Michael Mehling*
}

\section{INTRODUCTION}

The Paris Agreement established a new international framework for the parties to the United Nations Framework Convention on Climate Change (UNFCCC) from 2020 onwards. Climate policy will be based on national contributions to mitigation, adaptation, and financial, technological and capacity-building support. At the international level, regular reviews of national efforts will help strengthen transparency and are expected to drive national ambitions to meet the goal of keeping the global average temperature increase below two degrees Celsius, compared to pre-industrial levels. In order to achieve success, this new regime needs support from other policy regimes. The trade policy agenda is among the most important because trade liberalization can, on the one hand, promote the uptake of climate-friendly goods and services and foster the deployment of clean technologies; however, on the other hand, national climate policy measures can collide with trade rules due to conflicting principles and priorities.

Countries following up on their nationally-determined contributions (NDCs) will need access to clean technologies, not only in energy efficiency and renewable energy production, but in all areas where harmful greenhouse gases require abatement. At the same time, national climate policy measures can collide with trade rules due to conflicting principles and priorities, e.g., protectionism, and

\footnotetext{
* Susanne Droege, Senior Fellow, Global Issues Research Division at the German Institute for International and Security Affairs, Berlin, Germany; Harro van Asselt, Senior Research Fellow, Stockholm Environment Institute (SEI) Oxford Centre, Oxford, United Kingdom, and Professor of Climate Law and Policy, University of Eastern Finland Law School, Joensuu, Finland; Kasturi Das, Associate Professor of Economics and International Business, Institute of Management Technology, Ghaziabad, India; Michael Mehling, Deputy Director, Center for Energy and Environmental Policy Research (CEEPR) at the Massachusetts Institute of Technology (MIT), USA, and Visiting Professor, University of Strathclyde Law School, Glasgow, United Kingdom. This article was made possible through funding by the KR Foundation for the project "Making the Trading System Work for Climate Change" (2016-2017). The authors wish to express their gratitude to Felix Schenuit for valuable research assistance, and to Henry Derwent for thoughtful comments on an earlier draft of the article.
}

A peer-reviewed, accepted author manuscript of the following research article: Susanne, D., van Asselt, H., Das, K., \& Mehling, M. (2017). The trade system and climate action : ways forward under the Paris Agreement. South Carolina Journal of International Law \& Business, 13(2), 195-277. 
these trade rules therefore need to be discussed and evaluated with a view to their potential to support climate policy without compromising trade.

The political climate in two important regions, the European Union (EU) and in the United States (US), has changed considerably since the entry into force of the Paris Agreement on November 4, 2016. With the newly elected US President Donald J. Trump in office, US climate policy and liberalized trade both have come under pressure under the "America First" approach endorsed by the President and his administration. This may have severe ramifications for the implementation of international climate policy, ${ }^{1}$ with deregulation emerging as a key prong of the new administration's policies, as well as looming threats to withdraw from the international climate regime. The US's current administration significantly implicates trade policy, considering President Trump already withdrew from the Trans-Pacific Partnership on his fourth day in office. These changes pose new challenges for trade and climate policy interactions, as exemplified by the international reactions to a potential US withdrawal from the Paris Agreement.

As climate policy has become a major field in international policy, its standing vis-à-vis the well-established World Trade Organization (WTO) regime is changing rapidly. With the increasing importance of national measures following the adoption of the Paris Agreement, synergies and conflicts can be expected to change over time. An indicator of such adjustments are WTO disputes that have emerged in recent years, which center on renewable energy production and trade in related goods and services. The inclusion of environmental and climate policy provisions in regional trade agreements (RTAs) further show there is a demand for policy coordination.

This article reviews the interactions between climate and trade policy by providing an overview of the two regimes, focusing on legal and political dimensions. In particular, we assess the interactions between the climate regime's policy measures with the trade regime of the WTO, as well as aspects that emerge from RTAs. We focus on the question of how the international trade regime could support efforts in tackling climate change.

Part I introduces climate change and trade regimes (including the WTO and RTAs). Part II gives an overview of the trade rules and their relevance for climate

${ }^{1}$ Susanne Droege, International Climate Diplomacy after the Trump Election Victory: Germany and the EU Should Intensify Their Outreach to Climate Allies, SWP COMMENTS 50, 2-4, (November 2016). 
policy. Part III illustrates the interactions between international and national climate policy approaches and trade policies. Part IV summarizes suggested solutions to avoid conflicts and strengthen synergies between the regimes.

\section{THE CLIMATE AND TRADE REGIMES: AN OVERVIEW}

\section{A. THE CLIMATE REGIME}

The UNFCCC was adopted in 1992 at the Rio Conference on Environment and Development. ${ }^{2}$ With 196 parties, it has nearly universal participation. ${ }^{3}$ It sets out the main objective of the climate regime as "stabilization of greenhouse gas concentrations in the atmosphere at a level that would prevent dangerous anthropogenic interference with the climate system."4 However, the Convention did not specify legal obligations to achieve this objective. In 1995, parties started negotiating a protocol to stipulate mitigation targets for developed countries. This led to the adoption of the Kyoto Protocol in 1997, which now has 192 parties. ${ }^{5}$ The Protocol requires industrialized countries to collectively reduce average greenhouse gas emissions by 5.2\% during 2008-12 (i.e., the first commitment period), compared to 1990 levels. ${ }^{6}$ As an innovative next step, it introduced several market-based instruments ("flexible mechanisms") to allow for cost-effective mitigation. ${ }^{7}$ While developing countries signed and ratified the Kyoto Protocol, they do not have any concrete obligations to reduce their emissions. With the 2012 Doha Amendment to the Kyoto Protocol, parties agreed on a new commitment period for 2013-20. However, the amendment has yet to enter into force.

Throughout the history of the climate regime, a recurring question has been who should act to reduce greenhouse gas emissions and how the effort to address climate change should be shared. The UNFCCC establishes the principle of common but differentiated responsibilities and respective capabilities, which was initially translated into a bifurcated division of Annex I (developed countries) and non-Annex I countries (developing countries). ${ }^{9}$ The Kyoto Protocol followed this

\footnotetext{
${ }^{2}$ United Nations Framework Convention on Climate Change, May 9, 1992, S. Treaty Doc. No. 10238, 1771 U.N.T.S. 107 [hereinafter UNFCCC].

${ }^{3}$ See id.

${ }^{4} I d$. at art. 2.

5 See Kyoto Protocol to the United Nations Framework Convention on Climate Change, Dec. 10, 1997, U.N. Doc FCCC/CP/1997/7/Add.1, 37 I.L.M. 22 [hereinafter Kyoto Protocol].

${ }^{6}$ See id.

${ }^{7}$ See id.

${ }^{8}$ See id.

${ }^{9}$ UNFCCC, supra note 2, at art. 4.
} 
approach, which only required Annex I countries to mitigate emissions. ${ }^{10}$ As the pressure rose quickly to broaden participation of countries - particularly major emerging economies such as China, which surpassed the US as the world's largest emitter in the late $2000 \mathrm{~s}$ - in mitigation efforts, parties launched negotiations on a new climate treaty under the UNFCCC with the Bali Road Map in 2007. ${ }^{11}$ The purpose of a new agreement was to establish a genuinely global effort for long-term climate policy. In 2009, after the 15th UNFCCC Conference of the Parties (hereinafter "COP") in Copenhagen did not succeed in adopting a new global agreement, 12 it took another six years of negotiations to find a consensus in Paris at COP21. ${ }^{13}$

The Paris Agreement was adopted by the 196 parties to the UNFCCC on December 12, 2015, is signed by 194 states, and is ratified by over 120 states. $^{14}$ The Agreement entered into force on November 4, 2016. ${ }^{15}$ Its purpose is threefold: (1) to limit the global average temperature increase to "well below" 2 degrees Celsius above pre-industrial levels and "to pursue efforts" to achieve 1.5 degrees Celsius; (2) to enhance the ability to adapt to climate change, to increase the resilience and to establish low-greenhouse gas development; and (3) to make financial flows consistent with a low emissions pathway and climate resilient development. ${ }^{16}$ Unlike the Kyoto Protocol, the core obligations under the Paris Agreement apply universally to all UNFCCC parties, not just developed country parties. ${ }^{17}$ The Paris Agreement requires all parties to prepare and communicate nationally determined contributions (NDCs) which must be reviewed and updated every five years, with each

\footnotetext{
${ }^{10}$ Kyoto Protocol, supra note 5, at art. 2-3.

${ }^{11}$ See generally U.N. Framework Convention on Climate Change, Bali Climate Change Conference - -December 2007, http://unfccc.int/meetings/bali_dec_2007/meeting/6319.php (briefly summarizing the outcome of the 13 th Convention of the Parties and the basic contours of the "Bali Road Map").

12 See generally U.N. Framework Convention on Climate Change, Copenhagen Climate Change Conference -December 2009, http://unfccc.int/meetings/copenhagen_dec_2009/meeting/6295.php (noting the parties made significant progress towards common climate goals (for example. keeping temperature rise under two degrees Celsius) but did not reach an actual agreement as to the execution of those goals).

${ }^{13}$ See generally U.N. Framework Convention on Climate Change, Paris Climate Change Conference-November 2015, http://unfccc.int/meetings/paris_nov_2015/session/9057/php/view/decisions.php\#c (noting the parties reached an actual agreement as to how best to implement the goals of the aforementioned 15th COP). For an overview of the new regime, see Susanne Droege, The Paris Agreement 2015: Turning Point for the International Climate Regime, GERMAN INSTITUTE FOR INTERNATIONAL AND SECURITY AFFAIRS (Feb. 2016).

${ }^{14}$ See Paris Agreement, Dec. 12, 2015, 2016 T.I.A.S. No. 16-1104 [hereinafter Paris Agreement], https://www.state.gov/documents/organization/266403.pdf.

${ }^{15}$ See id.

${ }^{16}$ See id. at art. 2.

${ }^{17}$ See id. at art. 3.
} 
new NDC required to be more ambitious than the previous one. ${ }^{18}$ The Agreement further specifies actions in regard to adaptation ofNDCs, as well as obligations related to the "means of implementation" (i.e., financial, technological, and capacitybuilding support). ${ }^{19}$ Although the contents of NDCs are up to parties, the Agreement puts in place several mechanisms to review implementation and progress made, including a transparency framework to review NDC implementation, a mechanism to facilitate implementation and promote compliance, and a five-yearly global assessment to review collective progress. ${ }^{20}$

The UNFCCC and the Kyoto Protocol both include explicit references to trade policy concerns. The language used is partly identical to that found in the General Agreement on Tariffs and Trade (GATT), ${ }^{21}$ aimed at preventing protectionist applications of climate policy measures. ${ }^{22}$ The Paris Agreement, by contrast, does not contain any references to trade, mainly due to diverging positions of developed and developing countries. ${ }^{23}$ Following the Bali Action Plan in 2007, proposals by developing countries surfaced to include text in an international agreement that would prohibit developed countries from using unilateral trade measures on climate grounds. ${ }^{24}$ However, such proposals were usually accompanied by counter-proposals by developed countries to include no text on the issue at all. ${ }^{25}$

To offer institutional space for discussing such critical issues, in 2010 the parties created a forum regarding the impact of the implementation and response

${ }^{18}$ See id. at art. 4. In 2015, parties to the UNFCCC submitted their intended nationally determined contributions (INDCs), which must be updated and turned into NDCs under the Paris Agreement.

${ }^{19}$ See id. at art. 9-11.

${ }^{20}$ See id. at art. 13-15.

${ }^{21}$ General Agreement on Tariffs and Trade, Oct. 30, 1947, 61 Stat. A-11, 55 U.N.T.S. 194 [hereinafter GATT]. Article 3.5 of the UNFCCC (1992) states climate policy measures should not "constitute a means of arbitrary or unjustifiable discrimination or a disguised restriction on international trade."

${ }^{22}$ UNFCCC, supra note 2, at art. 3.

${ }^{23}$ See Paris Agreement, supra note 14, at art. 3.

${ }^{24}$ See, e.g., U.N. Framework Convention on Climate Change, Proposals by India for inclusion of additional agenda items in the provisional agenda of the seventeenth session of the Conference of the Parties, U.N. DoC. FCCC/CP/2011/INF.2/Add.1, at 7 (Oct. 7, 2011).

25 See Harro van Asselt, The Fragmentation of Global Climate Governance: ConseQUENCES AND MANAGEMENT OF REGIME INTERACTIONS (2014); Nicholas Chan, The New Impacts of the Implementation of Climate Change Response Measures, REV. OF EUR., COMP. \& INT'L ENVTL L., 228, 234-35 (2016). 
measures ${ }^{26}$ Because the Paris Agreement does not give guidance on trade and climate change, the forum is the primary institutional space for ongoing discussions on trade-related concerns in the context of the UNFCCC. ${ }^{27}$ The work of the forum must take into account "all relevant policy issues of concern." ${ }^{28}$ Although the work program of the forum does not directly tackle the climate-trade overlap, technical work on assessing the impacts of response measures suggest trade-related impacts will be considered. ${ }^{29}$ In particular, the UNFCCC guidance on the impact assessment of response measures on developing countries mentions trade impacts from tariffs and border carbon adjustments (BCAs). ${ }^{30}$

\section{B. THE WORLD TRADE REGIME}

\section{THE WTO}

The origins of the world trade regime date back to 1947 when GATT was adopted. ${ }^{31}$ Nearly half a century later, the WTO was established following the conclusion of the Uruguay Round of trade negotiations (1986-94). The WTO, with its 164 members, is the institutional umbrella of a series of six sub-categories of agreements, including fourteen agreements on trade in goods (e.g. GATT) and five other types of agreements, such as the General Agreement on Trade in Services (GATS) and the Agreement on Trade-related Aspects of Intellectual Property Rights (TRIPS). ${ }^{32}$

The key objective of the GATT is to promote the liberalization of trade in goods for the benefit of its members. ${ }^{33}$ It sets out a number of trade principles,

${ }^{26}$ See U.N. Framework Convention on Climate Change, Report of the Conference of the Parties on its sixteenth session, held in Cancun from 29 November to 10 December 2010, U.N. Doc. FCCC/CP/2010/7/Add.1, (Mar. 15, 2011).

${ }^{27}$ See UNFCCC, supra note 2, at art. 4; Paris Agreement supra note 14, at art 4.15; Ralph Bodle et al., The Paris Agreement: Analysis, Assessment and Outlook, GERMAn FED. EnV'T AGENCY 20 (2016); Chan, supra note 25, at 228-37.

${ }^{28}$ See U.N. Framework Convention on Climate Change, Report of the Conference of the Parties on its twenty-first session, held in Paris from 30 November to 13 December 2015, U.N. Doc. FCCC/CP/2015/10/Add.2 (Jan. 29, 2016).

${ }^{29}$ See generally U.N. Framework Convention on Climate Change, Forum on the Impact of the Implementation of Response Measures, http://unfccc.int/cooperation_support/response_measures/items/7418.php (last visited Apr. 9, 2017).

${ }^{30}$ See U.N. Doc. FCCC/CP/2010/7/Add.1, supra note 26, at Sec. III, Sub-Sec. A.

${ }^{31}$ See GATT, supra note 21.

32 Marrakesh Agreement Establishing the World Trade Organization annex 1, Apr. 15, 1994, 1867

U.N.T.S. 154 [hereinafter Agreement Establishing WTO].

33 See GATT, supra note 21. 
most notably that trade measures imposed by a member shall not discriminate between different trade partners (known as the most-favored nation (MFN) obligation). ${ }^{34}$ Neither shall trade measures discriminate against imported goods from other members vis-à-vis "like" domestic goods (the national treatment obligation). ${ }^{35}$ These key non-discrimination principles were derived from the concept of comparative advantage, which increases welfare for two reasons: countries can specialize in products for which they have abundant resources, and with higher production there will be economies of scale. Free trade also allows a country to benefit from a wider variety of consumer goods offered by producers from other countries.

Although initial rounds of trade talks under the GATT were devoted to bringing down tariffs, later negotiation rounds (starting with the Tokyo Round, 1973-79) broadened the scope to non-tariff barriers, such as import licensing, rules of origin, and investment measures. ${ }^{36}$ Over time, the multilateral trade regime came to cover new areas, such as services,${ }^{37}$ intellectual property rights, ${ }^{38}$ technical standards, ${ }^{39}$ and subsidies. ${ }^{40}$

An important feature of the WTO is its strong dispute settlement mechanism, which extends the GATT's practice. ${ }^{41}$ Under the integrated system of dispute settlement created alongside the WTO, the same dispute settlement rules apply to disputes under virtually all WTO agreements, subject to any special or additional rules in an individual agreement. ${ }^{42}$ The politically desirable outcome of a dispute is a resolution of the conflict through consultations, or, more generally, a solution mutually acceptable to the parties to the dispute. If this is not possible, the next primary objective of the process is to withdraw the measure under contention, with

${ }^{34} \mathrm{Id}$. at art. I. More specifically, a WTO member is obliged to provide to another WTO member treatment which is "no less favourable" than what it accords to any other country, irrespective of whether that country is a WTO member.

${ }^{35} I d$. at art. III.

${ }^{36}$ See GATT, supra note 21.

37 See General Agreement on Trade in Services, Apr. 15, 1994, 1869 U.N.T.S., 33 I.L.M. 1167 [hereinafter GATS].

38 See Agreement on Trade-Related Aspects of Intellectual Property Rights, Apr. 15, 1994, 1869 U.N.T.S. 299, 33 I.L.M. 1197 [hereinafter TRIPS Agreement].

39 See Agreement on Technical Barriers to Trade, Apr. 15, 1994, 1868 U.N.T.S. 120 [hereinafter TBT].

${ }^{40}$ See Agreement on Subsidies and Countervailing Measures, Apr. 15, 1994, 1869 U.N.T.S. 14 [hereinafter SCM].

${ }^{41}$ Agreement Establishing WTO, supra note 32, at art. III.

${ }^{42}$ Id. at Annex 2. The WTO's Dispute Settlement Understanding (DSU) specifies the scope of jurisdiction of the WTO dispute settlement mechanism, limiting it to the "covered agreements" listed in Article 1.1. 
compensation and retaliation being avenues of last resort. ${ }^{43}$ In contrast to the GATT's diplomatic norms, which were criticized for lacking the teeth necessary to ensure compliance, the dispute settlement mechanism has been described as "the most developed dispute settlement system in any existing treaty regime." 44 The system has been used intensively since the WTO came into being: the total 500 disputes over the 20-year history of the WTO is in stark contrast to the 300 total disputes brought under the dispute settlement system of the GATT - the predecessor to the WTO - over a period of 47 years, from 1947-94. ${ }^{45}$

In 2001, a new round of trade talks, known as the Doha Development Round, was launched to expressly address issues of importance to developing countries. The Doha Round includes negotiations on the reduction or elimination of tariffs and non-tariff barriers on environmental goods and services, and paragraph 31 of the Doha Ministerial Declaration acknowledges the relationship between existing WTO rules and specific trade obligations set out in multilateral environmental agreements. ${ }^{46}$ The Doha Round negotiations use a "single undertaking" approach where countries agree on all issues together. ${ }^{47}$ This prevents countries from cherry-picking issues, but makes consensus more challenging. The Doha Round largely came to a halt in 2008, and little progress has been made since then. Nevertheless, WTO members managed to reach agreement on the 2013 "Bali package"48 and the 2015 "Nairobi package."49 However, at the Nairobi Ministerial in 2015, important disagreements persisted among WTO members on the best way forward, leading to a stalemate in the trade talks. ${ }^{50}$

Multilateral trade ambitions have faded since the 1990s due to a host of factors, such as emerging markets, shifting powers, and related national and regional interests, all on top of the large number of trade-related issues that are more

${ }^{43}$ Daniel T. ShedD ET Al., Cong. Research Serv., RS20088, Dispute SeTtlement IN THE WORLD TRADE ORGANIZATION (WTO): AN OVERVIEW 3 (2012),

${ }^{44}$ David Palmeter, The WTO as a Legal System, 24 FORDHAM INT’L L. J. 444, 479 (2000).

45 WTO Director-General, WTO Annual Report 2016102 (2016), https://www.wto.org/english/res e/booksp e/anrep e/anrep16 chap6 e.pdf.

46 World Trade Organization, Ministerial Declaration of 14 November 2001, WTO Doc. WT/MIN(01)/DEC/1, 41 ILM 746 (2002) [hereinafter Doha Declaration].

${ }^{47} \mathrm{Id}$. at 47.

${ }^{48}$ World Trade Organization, The Bali Ministerial Declaration of 7 December 2013, WTO Doc. WT/MIN(13)/DEC (2013) (covering trade facilitation, food security in developing countries, and cotton trade).

${ }^{49}$ World Trade Organization, Ministerial Declaration and Decisions of 19 December 2015, WTO Doc. WT/MIN(15)/45-WT/L/980 (2015) (including an agreement to eliminate agricultural export subsidies).

${ }^{50}$ Overview of Outcomes of WTO's 10th Ministerial in Nairobi, ICTSD BRIDGES DAILY UPDATE, No. 5, at 1 (Dec. 19, 2015). 
complicated to negotiate than tariff rates. Generally, the WTO's relevance for global trade has always depended on the willingness of WTO members to bring negotiations forward. Contrary to its diminishing relevance in international trade law-making, the WTO's dispute settlement system is still a very strong institutional tool, and is used regularly by members. Given concerns about climate policy measures' potential to violate WTO rules, dispute settlement takes a key role in providing legal clarity in cases of conflict (see also Part II.C).

By contrast, the number of RTAs has risen sharply. RTAs, of which megaregional agreements are a sub-category, have to be notified to the WTO in accordance with Article XXIV of GATT. ${ }^{51}$ In addition, under the WTO umbrella, there are two stand-alone plurilateral agreements, as well as plurilateral agreements that extend concessions to all WTO members on an MFN basis. The ongoing negotiations on a plurilateral Environmental Goods Agreement fall in the latter category, meaning the benefits of the agreement will apply to all WTO members once it is adopted.

Environmental concerns are acknowledged in the preamble to the 1995 Agreement Establishing the WTO, which contextualizes the goals of the trade regime so as to "[allow] for the optimal use of the world's resources in accordance with the objective of sustainable development." 52 The WTO's Committee on Trade and Environment (CTE) offers the institutional setting for elaborating the relationship between trade measures and environmental measures and for promoting sustainable development within the WTO. The CTE is open to all WTO members and to observers from intergovernmental organizations, including the UNFCCC Secretariat. Since the start of the Doha Round, the CTE has convened in Special Sessions to discuss the environmental aspects of the Doha Development Agenda. However, in recent years, limited progress has been made, in part due to the general stalemate in the Doha Agenda, and also due to developments at the regional level (as discussed below). Although climate change hardly was featured in WTO discussions until 2007, under the leadership of WTO Director General Pascal Lamy (2005-13), the organization became actively involved in discussions on the climate and trade interface, notably leading to a joint report with the United Nations Environment Programme on the subject in 2009. ${ }^{53}$ Since the 1990s, the interface between trade and the environment - including, more recently, climate change- - has come to the fore primarily through GATT/WTO case law. Although individual cases have not

${ }^{51}$ See GATT, supra note 21.

${ }^{52}$ Agreement Establishing WTO, supra note 321, preamble.

${ }^{53}$ WTO Secretariat and U.N. Environmental Programme, Trade and Climate Change: A Report by the United Nations Environment Programme and the World Trade Organization, WTO ISBN 97892-870-3522-6 (2009). 
led to major frictions between the two regimes, the implementation of the Paris Agreement, with nationally driven climate action as a key approach, will lead to further demand for discussing and clarifying how the regimes could interact in a productive way (see Part IV).

\section{REGIONAL TRADE AGREEMENTS}

During the Uruguay Round of trade negotiations, many GATT members turned to regional or bilateral trade agreements. The formation and strengthening of major trade blocs in the Americas (i.e., the North American Free Trade Agreement (NAFTA) and Mercado Común del Sur (MERCOSUR)) and Europe in the late 1980s and early 1990s incentivized other countries to either join or to establish their own agreements. ${ }^{54}$ Against the backdrop of globalization, RTAs were perceived to help enhance market access, promote foreign policy objectives, and influence the policies of trading partners. ${ }^{55}$ As a result, the number of RTAs has increased significantly in the last two decades, leading to a "spaghetti bowl" of trade agreements. ${ }^{56}$ By February 2016, the WTO received 625 notifications of RTAs, 419 of which were in force at that time, compared to 124 notifications to the GATT between 1948 and 1994. ${ }^{57}$

In recent years, the discussion of regionalism in the trade context has taken a new turn with the emergence of "mega-regional" agreements. ${ }^{58}$ Negotiations on the EU-Canada Comprehensive Economic and Trade Agreement (CETA) were concluded in August 2014, but only obtained EU approval after intense political struggles in 2016. The Trans-Pacific Partnership (TPP, bringing together Australia, Brunei, Canada, Chile, Japan, Malaysia, Mexico, New Zealand, Peru, Singapore,

${ }^{54}$ Richard E. Baldwin, The Causes of Regionalism, 20 THE WORLD ECONOMY 865, 870-71 (1997).

55 See generally Theresa Carpenter, A Historical Perspective on Regionalism, in MuLTILATERALIZING Regionalism: Challenges For the Global TRAding System 13, 13-27 (Richard Baldwin \& Patrick Low eds., 2009).

${ }^{56}$ See Jagdish Bhagwati, Regionalism versus Multilateralism, 15 THE WORLD ECONOMY 535, 535556 (1992).

57 See WTO, Evolution of Regional Trade Agreements in the World, 1948-2016, Regional Trade Agreements: Facts and Figures, https://www.wto.org/english/tratop_e/region_e/regfac_e.htm (last visited Apr. 10, 2017).

${ }^{58}$ Rep. of the World Economic Forum, Global Agenda Council on Trade \& Foreign Direct Investment, Mega-regional Trade Agreements: Game-Changers or Costly Distractions for the World Trading System?, 13, WEF REF $160414 \quad$ (July 2014) http://www3.weforum.org/docs/GAC/2014/WEF_GAC_TradeFDI_MegaRegionalTradeAgreements_Re-

port_2014.pdf [hereinafter WEF Report]. The WEF Report defines mega-regionals as "deep integration partnerships in the form of RTAs between countries or regions with a major share of world trade and foreign direct investment (FDI), and in which two or more of the parties are in a paramount driver position, or serve as hubs, in global value chains." 
the United States and Vietnam) was signed in February 2016. Given that the newly elected US President Donald Trump has announced his administration would revoke the agreement, the future of this mega-regional is uncertain. ${ }^{59}$ Likewise, the negotiations on the Transatlantic Trade and Investment Partnership (TTIP) between the EU and the US are regarded as "frozen" after the election of President Trump, ${ }^{60}$ as are the negotiations for the Regional Comprehensive Economic Partnership (RCEP), involving ten ASEAN members, along with China, Japan, South Korea, India, Australia and New Zealand. The EU, the exclusive competence on trade relations, which was deepened under the 2009 Lisbon Treaty, has been questioned by these conflicts around mega-regional agreements. Given the protectionist agenda of the new US government's administration, chances for the conclusion of new RTAs are also minimal for the timebeing.

Still, the mega-regionals are not only important because of the parties involvedincluding some of the world's major trading nations - but also because of their expansive scope, which covers not only market access but also regulatory coherence. Given their scope and membership, the success or failure of mega-regionals may influence multilateral rule development. Success may mean future multilateral rules may be modelled after the mega-regionals. ${ }^{61}$ Success also may lead to fewer RTAs, helping to clean up the spaghetti bowl. ${ }^{62}$ However, success is not guaranteed because the various mega-regionals have come under significant scrutiny, triggered partly by civil society demands for transparency and partly by political opposition.

Environmental provisions have become increasingly prevalent in RTAs. NAFTA set the stage by including a side-agreement, the North American Agreement on Environmental Cooperation, with other US RTAs following suit. The EU also started to incorporate environmental provisions in its RTAs with third countries since the mid-1990s. EU trade agreements with third countries are also linked to an increasing number of multilateral environmental agreements, while US trade agreements have become increasingly specific about the environmental action re-

${ }^{59}$ Cristian Rodriguez Chiffelle, As Trump ditches the TPP, what's next for the world's biggest trade deal?, InTERNATIONAL CENTRE FOR TRADE AND SUSTAINABLE DEVELOPMENT (Dec. 12, 2016), , http://www.ictsd.org/opinion/as-trump-ditches-the-tpp-what.

${ }^{60}$ Philip Blenkinsop, U.S. trade talks in deep freeze after Trump win, says EU, REUTERS (Nov. 11, 2016, 11:51 AM EST), http:/www.reuters.com/article/us-usa-election-eu-tradeidUSKBN1361UN.

${ }^{61}$ Richard Baldwin, Multilateralising 21st Century Regionalism, in OECD, GLOBAL FORUM ON TRADE: RECONCILING REgIONALISM AND MultilAtERALISM IN A POST-BALI WorLD, 6 (Feb. 1112, 2014), https://www.oecd.org/tad/events/OECD-gft-2014-multilateralising-21st-century-regionalism-baldwin-paper.pdf.

${ }^{62}$ WEF Report, supra note 58, at 26. 
quired, backed up by consultations and dispute-settlement procedures in the agreements. ${ }^{63}$ The trend of including environmental provisions is continuing also in the negotiation of mega-regionals. Chapter 20 of the TPP and Chapter 24 of CETA are dedicated in their entirety to environmental issues, and a chapter on trade and sustainable development is the subject of ongoing TTIP negotiations.

\section{THE INTERACTIONS BETWEEN THE REGIMES}

With the adoption of the Paris Agreement, the climate regime has witnessed an evolution towards a universal regime, requiring mitigation efforts from all parties but leaves open what kind of action parties should or may undertake. The shift towards a "bottom-up" approach to international climate policy has potential implications on trade because the resulting flexibility allows for a variety of measures that could have trade implications and for which a supportive trade policy setting would be helpful.

The international trade regime also has undergone significant changes in recent years. Although a well-established system of trade rules has been in place for over twenty years, and WTO members now include the world's major trading nations, the single-undertaking approach that led to the WTO has created difficulties. Flanked by an increasing number of RTAs and, more recently, by new megaregional agreements, the relevance and dominance of the WTO in setting international trade rules has been challenged. In turn, the WTO's dominant position may offer both opportunities and risks for global climate protection because there is a lack of guidance on the one hand, and of space for new mutually supportive rules on the other.

The two regimes have so far co-existed without creating severe frictions. ${ }^{64}$ However, this may not be the case in the future with the recent emergence of several climate-related disputes. The fact that both regimes find themselves at a crossroads may also lead to new opportunities to create rules and procedures that lead to benefits for climate change, trade, and development.

\footnotetext{
${ }^{63}$ See Sikina Jinnah \& Elisa Morgera, Environmental Provisions in American and EU Free Trade Agreements: A Preliminary Comparison and Research Agenda, 22 REV. OF EUR., COMP. \& INT'L ENVTL. L. (2013). Review of European, Comparative \& International Environmental Law.

${ }^{64}$ See HARRO VAN ASSELT, supra note 25, at 166; Robyn Eckersley, Understanding the Interplay Between the Climate and Trade Regimes, in CliMATE AND TRADE POLICIES IN A POST-2012 WORLD (Geneva: UNEP) 11, 11-18 (Benjamin Simmons et al. eds., 2009).
} 


\section{TRADE PROVISIONS AND DISPUTES THAT RELATE TO CLIMATE POLICY}

There are a number of general and specific clauses and rules under the WTO, as well as disputes and cases, that are relevant for countries implementing national or international climate policy measures. We list the key clauses and disputes and highlight their relevance for future climate policy making.

\section{A. THE GATT RULES AND CLIMATE POLICY}

The trade rules under the WTO are based on the principles of transparency, predictability, and stability. ${ }^{65}$ The WTO trade rules' purpose is to reduce transaction costs for the WTO members and to provide a basis for applying trade measures among WTO members. Article I of GATT sets up the MFN obligation that also creates a multiplier effect for bilateral talks: if one member agrees on a lower tariff with a trade partner, that tariff will apply automatically to all other WTO members such that discrimination among WTO members is avoided and requires a specific justification. ${ }^{66}$ Non-discrimination is key: non-discrimination is incorporated in Article III of GATT (the national treatment obligation), which demands imported products be treated on par with "like" domestically produced goods. ${ }^{67}$ Article II.2(a) of GATT allows a WTO member to impose a charge either on an imported product that is equivalent to an internal tax that the concerned member has imposed on like-domestic products or on an article from which the imported product has been produced in whole or in part. ${ }^{68}$ However, it also needs to be ensured that such a border tax adjustment abides by the national treatment requirements ${ }^{69}$ thus ensuring imported products are not discriminated against compared to like-domestic products.

Non-discrimination among WTO members, and among traded goods and domestically produced "like" products, poses challenges for climate policy making. ${ }^{70}$ The "likeness" of products as understood-though not defined-under the WTO regime is a key element of addressing emissions through climate policy

${ }^{65}$ See HARRO van Asselt, supra note 25, at 161.

${ }^{66}$ GATT, supra note 21 , art. I.

${ }^{67} I d$. at art. III.

${ }^{68} \mathrm{Id}$. at art. II.2(a).

${ }^{69} \mathrm{Id}$. at art. III(2).

${ }^{70}$ See Joost Pauwelyn, U.S. Federal Climate Policy and Competitiveness Concerns: The Limits and Options of International Trade Law (Nicholas Inst. for Envtl. Policy Sol., NI WP 07-02, 2007); see Joost Pauwelyn, Carbon Leakage Measures and Border Tax Adjustments under WTO Law, in RESEARCH HANDBOOK ON ENV'T, HEALTH AND THE WTO 448-506 (D. Prevost and G. v. Calster ed., Edward Elgar, 2013). 
measures. ${ }^{71}$ Emissions are often part of the production process and cannot be found in the physical characteristics of a traded good (i.e. they are non-product-related processes and production methods, or PPMs). Differentiation of imports or exports based on their non-product-related PPMs (e.g. their "embedded carbon") could be necessary at the border, but would need justification under the WTO rules. ${ }^{72}$ The legality of border carbon adjustments or carbon taxes applied to imported goods largely hinges on this particular point (see Part III.D).

Articles VI and XVI of GATT provide the basic principles on subsidies and countervailing duties (CVD) in the GATT/WTO system, whereas the Agreement on Subsidies and Countervailing Measures (SCM) is an implementation agreement. Article XVI "contains general provisions against subsidies that expand the exports of primary products or lower the export prices of other products below those prevailing in the domestic market." 73 Article VI provides for the imposition of "countervailing duties to offset subsidies granted, directly or indirectly, on the manufacture, production or export of any merchandise." "74 To impose a countervailing duty, however, "injury or threat of injury to an established industry must be determined.Alternatively, the subsidy must be shown to retard the establishment of an equivalent domestic industry." 75

Article XX of GATT contains a list of exceptions to the GATT rules. Nondiscrimination, for instance, can be suspended if certain conditions are met. Two of these exceptions relate to environmental concerns: if discrimination is "necessary to protect human, animal, or plant life or health"76 or if it relates to "the conservation of exhaustible natural resources if such measures are made effective in conjunction with restrictions on domestic production and consumption,"77 then discrimination is permissible. For all exceptions, the conditions stipulated in the introductory part (chapeau) of Article XX need to be met. Thus, any measure has to pass the test of "arbitrary or unjustifiable discrimination" or disguised trade restrictiveness. ${ }^{78}$ The UNFCCC and the Kyoto Protocol also use this wording (see Part

${ }^{71}$ Pauwelyn, U.S. Federal Climate Policy and Competitiveness Concerns, supra note 70; Pauwelyn, Carbon Leakage Measures, supra note 70.

${ }^{72}$ Pauwelyn, U.S. Federal Climate Policy and Competitiveness Concerns, supra note 70; Pauwelyn, Carbon Leakage Measures, supra note 70.

73 Arvind Panagariya, Core WTO Agreements: Trade in Goods and Services and Intellectual Property, 13, (2002).

${ }^{74} \mathrm{Id}$.

${ }^{75} \mathrm{Id}$.

${ }^{76}$ GATT, supra note 21 , at art. XX(b).

${ }^{77} \mathrm{Id}$. at art. $\mathrm{XX}(\mathrm{g})$.

${ }^{78}$ Aaron Cosbey et al., A Guide for the Concerned: Guidance on the Elaboration and Implementation of Border Carbon Adjustment, 9, ENTWINED (Policy Report No. 3, Nov. 2012), 
I.A, above). Article $\mathrm{XX}$ is a key clause for the discussion concerning how climate policy measures can be justified under, and supported by, the international trade regime because Article XX opens the way for policy measures deemed necessary to follow other than purely trade-centerd ambitions.

\section{B. OTHER WTO AGREEMENTS AND THEIR RELEVANCE FOR CLIMATE-AND TRADE POLICY INTERACTIONS}

In addition to the GATT, another set of agreements under the WTO are relevant for the interactions between climate and trade policy because they regulate either specific aspects of trade in goods (e.g. property rights or standards) or services. This part looks at the seven most important of these agreements in turn, and discusses their relevance for climate policy.

\section{GENERAL AGREEMENT ON TRADE IN SERVICES}

Pursuant to Article I.1 of GATS, the agreement applies to all "measures by Members affecting trade in services" covering "any service in any sector except services supplied in the exercise of governmental authority" 79 and extends to both direct and indirect effects on trade in services. ${ }^{80}$ The GATS approach to the liberalization of services applies positive lists (e.g., Schedules of Commitments), meaning that members identify those services they want to liberalize. The MFN principle applies accordingly. ${ }^{81}$

Policies adopted for climate change mitigation and adaptation that directly or indirectly affect trade in services are subject to scrutiny under the GATS if they fall within sectors or subsectors that are included in a member's Schedule of Commitments. The market for services related to climate protection is large and may even exceed the market for related goods. ${ }^{82}$ Because these services are spread

http://www.iisd.org/sites/default/files/publications/bca_guidance.pdf [hereinafter Cosbey et al. 2009].

${ }^{79}$ GATS, supra note 37 , at art. I.2.

${ }^{80}$ See Panel report, European Communities - Regime for the Importation, Sale and Distribution of Bananas, Complaint by Guatemala and Honduras, WTO Doc. WT/DS27/R/GTM, WT/DS27/R/HND (May 22, 1997) (affirmed GATS applies to both direct and indirect effects on trade).

${ }^{81}$ GATS, supra note 37 , at II.1.

${ }^{82}$ In the energy sector, the trade in energy is only made feasible through a series of supporting services, such as distribution and transportation, engineering, and financial services; see Panagiotis Delimatsis, GATS, Financial Services and Trade in Renewable Energy Certificates (RECS) - Just Another Market-based Solution to Cope with the Tragedy of Commons?, in INTERNATIONAL TRADE Regulation and the Mitigation of Climate Change. World Trade Forum 231-58 (T. Cottier, O. Nartova, \& S. Z. Bigdeli eds., 2009). 
across multiple sectors, however, it becomes difficult to identify and classify them under the established nomenclature. ${ }^{83}$ Moreover, because services related to energy or clean technologies are often traded in tandem with the corresponding goods, coordination between negotiations on goods and negotiations on services is necessary but often lacking. ${ }^{84}$

WTO negotiations on environmental services and their classification continue at the Special Session of the Committee on Trade in Services. ${ }^{85}$ For now, however, each measure is assessed on a case-by-case basis, subsuming the services in question under established sectors and subsectors listed in the Schedules of Commitments of individual members.

Slow progress with liberalization under the GATS is shifting items to the agenda of negotiations on regional or plurilateral trade agreements, such as the Trade in Services Agreement. ${ }^{86}$ When relating to climate-relevant services, therefore, greater normative fragmentation and geographic heterogeneity is a likely outcome going forward.

\section{AGREEMENT ON TRADE-RELATED INVESTMENT MEASURES}

Recognizing that certain investment measures can have trade-restrictive and distorting effects, the WTO Agreement on Trade-Related Investment Measures (TRIMS) prohibits the use of TRIMS that are inconsistent with Article III (national treatment) or Article XI (general elimination of quantitative restrictions) of GATT 1994 in Article 2.1 of the TRIMS Agreement. ${ }^{87}$ The Agreement applies to investment measures related to trade in goods only and does not cover trade in services, and its coverage is limited to the WTO rules mentioned. The term "trade-related investment measures" is not defined in the agreement. However, the agreement

\footnotetext{
${ }^{83}$ Joachim Monkelbaan, Trade in Sustainable Energy Services, INT'L CRT. FOR TRADE AND SUSTAINABLE DEV., 7-8 (Oct. 2013), http://www.ictsd.org/downloads/2013/10/trade-in-sustainble-energy-services.pdf.

${ }^{84} \mathrm{Id}$. at 1.

${ }^{85}$ See Informal Note by Secretariat, Environmental Services Overview of Classification Issues, WTO Doc. JOB/SERV/84 (Aug. 31, 2011).

${ }^{86}$ See COALITION OF SERVICES InDUSTRIES, The Trade In Services Agreement (TISA), https://servicescoalition.org/negotiations/trade-in-services-agreement (last visited Feb. 18, 2017).

${ }^{87}$ See David A. Ganz \& Padideh Ala'i, Climate Change Innovation, Products and Services Under the GATT/WTO System, in RESEARCH HANDBOOK ON INTELLECTUAL PROP. AND CLIMATE CHANGE 290 (J. D. Sarnoff ed., 2016).
} 
contains in an annex a non-exhaustive, illustrative list of measures that are inconsistent with Article III.4 or Article XI:1 of GATT 1994. The list includes certain mandatory and domestically enforceable measures imposed by WTO members, such as local content requirements (LCRs) for the production of goods, trade-balancing requirements (e.g. limiting the purchase or use of imported products to an amount related to the volume or value of exported products by an enterprise), exchange-balancing requirements (e.g. restricting access to foreign exchange to an amount related to the foreign exchange inflows to the enterprise), export restrictions, and so on.

The TRIMS Agreement has turned out to be one of the most cited WTO agreements in climate-related disputes that are dominated by cases about LCRs pertaining to renewable energy policies of various WTO members (see Part II.C). The TRIMS requirements for transparency in domestic rules and non-discrimination for investing in new energy production may clash with national employment and industrial policy strategies that are part of some NDCs. Thus, it is expected that trade partners will continue challenging national rules that discriminate against importers.

\section{AGREEMENT ON TRADE-RELATED ASPECTS OF INTELLEC- TUAL PROPERTY RIGHTS}

The TRIPS Agreement was created to protect intellectual property rights (IPRs) relating to traded products; for instance, products that can be counterfeited. TRIPS provides a minimum standard for domestic intellectual property laws of WTO members. Before the TRIPS Agreement, there was minimal international enforceability of IPRs due to a lack of stringent dispute settlement. ${ }^{88}$ The TRIPS Agreement covers copyrights and related rights; trademarks; geographical indications; industrial designs; patents (including plant variety protection); layout designs (topographies) of integrated circuits; and protection of undisclosed information including trade secrets and test data. ${ }^{89}$

IPRs play an important role as an incentive for technology development and innovation but also influence the transfer and diffusion of technologies. The objective of the TRIPS Agreement stipulates IPR protection is expected to contribute to both benefitting stakeholders and balancing rights and obligations. ${ }^{90}$ The agree-

${ }^{88}$ Peter K. Yu, Intellectual Property Enforcement and Global Climate Change, in RESEARCH HANDBook on InTEllectual PRoP. AND Climate Change (J. D. Sarnoff ed., , 2016).

${ }^{89}$ See TRIPS, supra note 38.

${ }^{90} \mathrm{Id}$. at art. VII. 
ment's "principles" recognize members' rights to adopt TRIPS Agreement-consistent measures to protect, inter alia, not only public health and nutrition but also the public interest in sectors of vital importance to their socio-economic and technological development. ${ }^{91}$ TRIPS-consistent measures may also be undertaken to prevent the abuse of IPRs by right holders, or "the resort to practices which unreasonably restrain trade or adversely affect the international transfer of technology", 92 Currently, the TRIPS Agreement protects patents for twenty years. ${ }^{93}$ Trade secrets, including tacit know-how, are covered by the agreement, which obliges members to protect information that is secret. ${ }^{94}$

Article 66.2 of the TRIPS Agreement requires developed countries to provide incentives to their enterprises and institutions for promoting and encouraging technology transfer to least developed countries. ${ }^{95}$ The agreement allows members to undertake measures by making use of certain "flexibilities" built into the agreement, such as non-voluntary or compulsory licenses, or a government use authorization for a patented technology, limited exceptions for non-commercial research, and so on. ${ }^{96}$ As affirmed by the 2001 Doha Declaration on the TRIPS Agreement and Public Health, each member has the right to grant compulsory licenses and the freedom to determine the grounds upon which such licenses are granted. Article 64 of the TRIPS Agreement requires that disputes regarding IPRs be settled by the WTO dispute settlement process. ${ }^{97}$ Part III of the TRIPS Agreement describes a set of norms to enforce IPRs protection using trade-related measures, but the standards for their application need updating in the light of very dynamic trends in international IPRs issues. ${ }^{98}$

Access to environmentally beneficial and climate-friendly technologies and know-how is a key driver of mitigation, and increasingly also of adaptation activities. The TRIPS Agreement strengthens the position of developers of climatefriendly technologies, but also demands a better dissemination via technology transfer. This position is particularly important for increasing emission reductions quickly by transferring innovative technologies to as many countries as possible, without securing a minimum amount of research and development cost coverage. The MFN provision guarantees certain measures that facilitate technology transfer

${ }^{91} I d$. at art. VIII.

${ }^{92} I d$. at art. $\operatorname{VIII}(2)$.

${ }^{93} I d$. at art. XXXIII

${ }^{94} I d$. at XXXIX(2).

${ }^{95} I d$. at art. $\operatorname{LXVI}(2)$.

${ }^{96} \mathrm{Id}$.

${ }^{97} \mathrm{Id}$. at art. LXIV.

${ }^{98}$ Peter K. Yu, supra note 89, at 2. 
towards selected countries are extended to all WTO members. The role of the TRIPS Agreement, however, is still not settled given ongoing debate on what constitutes technology transfer. Moreover, enforcement of IPRs protection via trade measures needs to be based on more precise common standards, and the TRIPS Agreement offers only rough guidance. ${ }^{99}$

\section{AGREEMENT ON TECHNICAL BARRIERS TO TRADE}

The TBT Agreement focuses on non-discrimination and is more specific than the GATT provisions. ${ }^{100}$ It establishes features specific to the preparation and application of regulatory measures that affect the trade in goods. ${ }^{101}$ Under the TBT Agreement, if a regulatory measure determines product characteristics or related production methods with which compliance is mandatory, this is considered a technical regulation. ${ }^{102}$ Technical regulations are allowed if they are applied equally to domestic and imported product and do not create "unnecessary obstacles to international trade."103 A document that determines rules, guidelines, or characteristics of products or related production methods with which compliance is voluntary is a standard under the TBT Agreement. ${ }^{104}$ If a measure sets out procedures that require the fulfilment of technical regulations or standards (i.e., testing, inspections, and certification), then this falls under conformity assessment procedures under the TBT Agreement. ${ }^{105}$

Following the TBT Agreement, mandatory climate regulations, such as fuel efficiency requirements for cars or mandatory energy labelling for products, would be considered technical regulations, whereas voluntary eco-labelling schemes referring to governmental standards would be considered a standard. To this end, technical regulations should not be more trade-restrictive than necessary to fulfil a legitimate objective, which includes the protection of the environment and the climate (as under Article XX GATT). Moreover, as the TBT Agreement strongly favors the use of international standards, it is sensible to develop standards through international cooperation. ${ }^{106}$ Yet it is uncertain whether the TBT Agreement also

\footnotetext{
${ }^{99} \mathrm{Id}$.

100 See TBT, supra note 39.

${ }^{101} \mathrm{Id}$. at Annex 1, para. 1.

102 Id. at Art. 2.

${ }^{103} I d$. at Art. 2, para. 2.2.

${ }^{104}$ See id. at Annex 1, para. 2 (also take heed of the definition's accompanying explanatory note).

${ }^{105}$ See $i d$. at Annex 1, para. 3 (note this explanatory note as well).

106 See generally Matthias Buck \& Roda Verheyen, Int'l Trade Law and Climate Change - A Positive Way Forward, FES-ANALYSE ÖKOLOGISCHE MARKTWIRTSCHAFT (2001).
} 
applies to non-product related PPMs. ${ }^{107}$ This means, for instance, that it is unclear whether the agreement applies to regulations specifying the permissible greenhouse gas emissions generated in the production of a good or mandatory labels indicating the carbon footprint of certain products.

\section{AGREEMENT ON SUBSIDIES AND COUNTERVAILING MEASURES}

The SCM Agreement adds precision to Article XVI of GATT by providing definitions of subsidies and clear disciplines on countervailing duties. It has the purpose of limiting use of subsidies by WTO members and includes rules for actions against a trade partner's subsidies. A country can charge a countervailing duty itself on subsidised imports if those are found to hurt the domestic producer. ${ }^{108}$ The SCM Agreement defines subsidies in Article 1.1. ${ }^{109}$ With reference to Article XVI GATT, any form of income or price support falls under the definition of subsidies. However, the subsidy identification holds only if a benefit is conferred through any of the transfer options listed. The key concept focuses on "specific" subsidies. ${ }^{110}$ Specific subsidies are available only to an enterprise, industry, group of enterprises, or group of industries in the subsidizing country. ${ }^{111}$ The SCM Agreement regulates these specific subsidies, which can be domestic or export subsidies. ${ }^{112}$ The agreement defines two categories: prohibited and actionable. Prohibited subsidies are contingent upon export performance or upon the use of domestic over imported goods. ${ }^{113}$ Those subsidies that fulfil the criteria of transferring a government financial contribution, being specific, and conferring a benefit are actionable. ${ }^{114}$ If a subsidy is not specific, it is non-actionable.

Domestic climate policy design could contradict the SCM Agreement if governments support domestic producers in a protectionist manner or differentiate prices for fuels at the border. In particular, the increasing interest in supporting

\footnotetext{
107 See Tracey Epps \& ANDrew GReEn, Reconciling TRADE AND Climate: How the WTO CAN HELP ADDRESS ClimATE CHANGE 78 (2010).

108 See generally Robert Howse \& Antonia Eliason, Domestic and International Strategies to Address Climate Change: An Overview of the WTO Legal Issues, in INTERNATIONAL TRADE REGULATION AND THE MitigAtion OF ClimATE CHANGE (Thomas Cottier et al. eds., 2009).

109 See id. at 11.

110 See id. at 54.

111 See generally id.

112 See generally id.

${ }^{113}$ SCM, supra note 40, at Art. 3.

${ }^{114}$ Id. at Art. 5. See generally Howse \& Eliason, supra note 110 (discussing whether the free access to polluting the atmosphere is an actionable subsidy as defined by the SCM Agreement).
} 
renewable energy production has led to direct and indirect subsidisation of domestic goods that are also exported. The rising number of WTO disputes (see Part II.C) mirrors this trend. By contrast, the SCM Agreement has not disciplined the extensive subsidization of fossil fuels in many WTO members. ${ }^{115}$ Given the pressing demands for reducing fossil fuel subsidies that stimulate greenhouse gas emissions, the WTO could play an important role in reforming national fossil fuel subsidies by acting as an information hub and providing guidance through the SCM rules. ${ }^{116}$

\section{ANTI-DUMPING AGREEMENT}

The Anti-Dumping Agreement clarifies and expands Article VI of GATT and provides the rulebook for WTO members to follow in their respective antidumping laws and practices. ${ }^{117}$ Members can act against dumping where there is "genuine ("material') injury to the competing domestic industry." 118 A member has to establish "dumping is taking place, calculate the extent of dumping (how much lower the export price is compared to the exporter's home market price), and show that the dumping is causing injury or threatening to do so." ${ }^{.19}$ It allows for charging extra import duties on the particular product from the particular exporting country to "bring its price closer to the 'normal value' or to remove the injury to domestic industry in the importing country." 20

Anti-dumping actions have been used by WTO members in the context of climate-related products, and for renewable energy products in particular. ${ }^{121}$ The fast-growing market for solar cells and panels and the market share increase by Chinese producers made first movers in European solar industry struggle with the dynamics of international trade and specialization. ${ }^{122}$ In 2013 the EU imposed twoyear anti-dumping and anti-subsidy duties against China for the protection of EU producers of solar panels.. ${ }^{123}$ If climate policy will create more new technologies that follow the example of solar panels, future dynamics in the markets for climate-

\footnotetext{
${ }^{115}$ See Liesbeth Casier et al., Shining a Light on Fossil Fuel Subsidies at the WTO: How NGOs Can Contribute to WTO Notification and Surveillance, INT'L INST. FOR SUSTAINABLE DEV. 19 (2014).

${ }^{116}$ See id. at 5; HARRO VAN ASSELT, supra note 25, at 15.

117 See WTO, Anti-dumping, subsidies, safeguards: contingencies, etc, https://www.wto.org/english/thewto_e/whatis_e/tif_e/agrm8_e.htm (last visited Jan. 1, 2017).

${ }^{118} \mathrm{Id}$.

${ }^{119} \mathrm{Id}$.

${ }^{120} \mathrm{Id}$.

${ }^{121}$ See generally European Commission Press Release, The European Union's Measures Against Dumped and Subsidised Imports of Solar Panels from China, CHAR/04/39 (Feb. 29, 2016).

${ }^{122}$ See generally id.

${ }^{123} \mathrm{Id}$.
} 
related goods may provoke more anti-dumping allegations because domestic industrial policy strategies collide with trade rules.

\section{AGREEMENT ON GOVERNMENT PROCUREMENT}

The Agreement on Government Procurement (GPA) aims at promoting transparency, integrity, and competition for government spending. The GPA emerged as one of the few multilateral agreements within the WTO legal framework. ${ }^{124}$ The "GPA has gained significance over time because procurement provisions in bilateral or regional trade agreements are modelled on its structures." 125

Government purchasing is a key means to establish demand for climatefriendly goods, such as low-emission transport or materials with a low-carbon footprint. In particular, countries with an ambitious climate policy often include "green" criteria in their tenders. This could lead to discrimination of imports if the criteria include non-product-related PPMs. The 2012 revision of the GPA introduced a new work program on the treatment of sustainable procurement. The work program covers the objectives of sustainable procurement, the ways in which it is integrated in national and sub-national policies, and the ways in which such procurement can be made consistent with the principle of "best value for money."

\section{WTO DISPUTE SETTLEMENT AND CLIMATE POLICY}

The trade and climate debate develops also with trade disputes and their settlement through case law. Over time, exporting countries have challenged various environmental requirements by importing countries on the grounds that they constitute protectionism, and that the importing country is exercising an unacceptable form of extraterritorial regulation in areas beyond its national jurisdiction. The U.S. fishing standards contested in the Shrimp/Turtle ${ }^{126}$ and the Tuna/Dolphin ${ }^{127}$ cases regulated non-product-related PPMs. Thus, the disputes touched on the key question of what features determine whether traded goods (e.g., tuna, shrimp) are

\footnotetext{
${ }^{124}$ Alan Herve \& David Luff, Trade Law Implications of Procurement Practices in Sustainable Energy Goods and Services, INT'L CTR. FOR TRADE \& SUSTAINABLE DEV. 1 (2012).

${ }^{125}$ Marc Steiner, The WTO Government Procurement Agreement: Assessing the Scope for Green Procurement, InT'L CTR. FOR TRADE \& SUSTAINABLE DEV. (Dec. 1, 2015).

${ }^{126}$ See generally Panel Report, United States - Import Prohibition of Certain Shrimp and Shrimp Products, WTO Doc. DS58, https:/www.wto.org/english/tratop_e/dispu_e/cases_e/ds58_e.htm (last visited Jan. 1, 2017).

${ }^{127}$ See generally Panel Report, United States - Restrictions on Import of Tuna, WTO Doc. DS21/R (Sept. 3, 1991); Panel Report, United States - Measures Concerning the Importation, Marketing and Sale of Tuna and Tuna Products, WTO Doc. WT/DS381/R (Sept. 15, 2011).
} 
"like" products if the process of their production differs with respect to environmental impacts (e.g., killing dolphins or turtles). Negative economic effects on the exporting countries were also part of the discussion because "PPMs can create financial and technological burdens" for developing countries' producers. ${ }^{128}$

Climate-related disputes are still a small proportion of the total number of disputes initiated under the WTO's dispute settlement system, yet the latest cases are linked to national climate policy targets. A growing tension is perceptible between trade rules and national renewable energy laws and policies. In addition, antidumping measures have increased, involving allegations related to unfair subsidies, the use of LCRs, or the calculations of countervailing duties. The Annex to this article lists the details of cases; here, we summarize the state of the disputes.

Five recent disputes relating to renewable energy and LCRs:

- Japan initiated the Canada - Renewable Energy case in 2010 against the province of Ontario's feed-in tariff (FIT) program. The Japanese claim was the program's LCRs discriminated against foreign renewable energy products, placed Canada in violation of national treatment requirements of the GATT and the TRIMS Agreement, and constituting a prohibited subsidy under the SCM Agreement. Canada argued its FIT was a form of government procurement to which the national treatment obligation did not apply, and the measure was designed to ensure the affordable generation of clean energy in Ontario. Consequently, Canada argued the measure was not subject to the WTO agreements cited. ${ }^{129}$ The EU had separately challenged the same FIT program in 2011. The WTO panels for these two cases acknowledged most of the claims by Japan and the EU, including the GATT and TRIMS violations, but were divided on the subsidy issue. Canada appealed the decisions. The Appellate Body (AB) in May 2013 held Ontario's FIT program violated the national treatment obligation under GATT and the TRIMs agreement, though it disagreed with the panel's analysis on a few points of law, including the subsidy determination. As a result, Canada had to bring its programs into compliance, which it did by mid-2014.

- The U.S. raised a second case on renewable energy, China - Measures Concerning Wind Power Equipment, in 2010 against China's Special Fund for Wind Power Equipment Manufacturing. It offered subsidies to Chinese wind turbine manufacturers that agreed to use key parts and components

\footnotetext{
${ }^{128}$ See Rafael Leal-Arcas, Unilateral Trade-related Climate Change Measures, 13 THE J. OF WORLD INV. \& TRADE 875, 889 (2012).

129 See Joanna I. Lewis, The Rise of Renewable Energy Protectionism: Emerging Trade Conflicts and Implications for Low Carbon Development, GLOBAL ENVTL. POL. 10, 19 (2014).
} 
made in China rather than imported parts. This case was chosen out of multiple U.S. investigations on China's renewable energy practices, including a series of anti-dumping and CVD investigations. ${ }^{130}$ The consultations that followed led to a revocation of the subsidy in 2011 by China. ${ }^{131}$

- In a parallel cases, China launched United States - Countervailing Duty Measures on Certain Products from China in May 2012 against several U.S. CVD investigations, which, among other things, addressed pricing of Chinese solar panels and wind towers. ${ }^{132}$ U.S. lobby groups alleged Chinese companies received unfair government support, leading to sales at below-market prices. ${ }^{133}$ In July 2014, a WTO panel found the U.S. practices on the calculation of CVDs to be in violation of certain provisions of the SCM and recommended the U.S. government bring its measures into conformity. As both China and the U.S. filed appeals on certain legal questions, the appellate body $(\mathrm{AB})$ had to take up the case. Its report was adopted with recommendations to bring the U.S. measures into conformity with WTO law. While the U.S. was reportedly implementing the DSB recommendations, China notified the WTO it was requesting consultations with the United States over the alleged non-compliance with the recommendations and rulings of the DSB. ${ }^{134}$

- In 2012, China launched the fourth dispute referring to LCRs, European Union and certain Member States - Certain Measures Affecting the Renewable Energy Generation Sector. China requested WTO consultations with the EU, Greece, and Italy on various FIT programs in support of solar energy generation that allegedly contained LCRs. China claimed that the

\footnotetext{
${ }^{130}$ See generally United Steelworker's Section 301 Petition Demonstrates China's Green Technology Practices Violate WTO Rules, UNITED STEELWORKERS, http://assets.usw.org/releases/misc/section-301.pdf (last visited Feb. 13, 2017) (outlining China's practices in violation of WTO policies). 131 See generally US Proclaims Victory in Wind Power Case; China Ends Challenged Subsidies, INT'L CTR. FOR TRADE \& SUSTAINABLE DEV. (June 8, 2011), http://www.ictsd.org/bridgesnews/bridges/news/us-proclaims-victory-in-wind-power-case-china-ends-challenged-subsidies.

${ }^{132}$ See US Probe into China, Vietnam Wind Tower Imports Moves Forward, INT'L CTR. FOR TRADE \& SUSTAINABLE DEV. (Feb. 15, 2012), http://www.ictsd.org/bridges-news/bridges/news/us-probeinto-china-vietnam-wind-tower-imports-moves-forward.

${ }^{133}$ See US-China Renewable Energy Row Escalates with Solar Duty Announcement, INT'L CTR. FOR TRADE \& SUSTAINABLE DEV. (May 23, 2012), http://www.ictsd.org/bridges-news/bridges/news/uschina-renewable-energy-row-escalates-with-solar-duty-announcement.

134 China requests consultations with US, WTO: DiSPUTE SETTLEMENT (May 13, 2016), https://www.wto.org/english/news_e/news16_e/ds437oth_13may16_e.htm.; see Statement by the United States at the Meeting of the WTO Dispute Settlement Body (Apr. 22, 2016), https://geneva.usmission.gov/wp-content/uploads/2017/02/Feb20.DSB_.Stmt_.pdf.
} 
measures were inconsistent with the GATT, SCM, and TRIMS agreements. The EU accepted the request for consultations, ${ }^{135}$ which are still pending.

- The U.S. initiated the fifth WTO dispute, India-Certain Measures Relating to Solar Cells and Solar Modules, in February 2013 against Indian LCR provisions pertaining to solar cells and/or modules. Under the Jawaharlal Nehru National Solar Mission (JNNSM), New Delhi aims at generating 100,000 mega-watts (MW) of grid-connected solar power capacity by 2022. ${ }^{136}$ The U.S. complained the LCRs were in violation of India's obligations under the GATT, TRIMS, and SCM agreements. The WTO established a panel in May 2014 to hear the case. India tried to persuade the U.S. to withdraw the case for several months through bilateral discussions. In its February 2016 report, the panel found the JNNSM's LCRs constituted trade-related investment measures, thus violating the national treatment obligation under the TRIMS agreement and the GATT. Moreover, the measures could not be exempted by the GATT's government procurement derogation, nor could they be justified by that agreement's general exceptions under Article XX(d), because the panel regarded them as neither "essential" nor "necessary". ${ }^{137}$ The panel also emphasized its analysis was of the WTO legality of the LCRs and the legitimacy of the policy objectives pursued through the JNNSM was not under dispute. ${ }^{138}$ In April, 2016, India appealed the case, but the AB ruled against India in September, 2016. ${ }^{139}$

135 European Commission, General Overview of Active WTO Dispute Settlement Cases Involving the EU as Complainant or Defendant and of Active Cases under the Trade Barriers Regulation, European Commission, http://trade.ec.europa.eu/doclib/docs/2016/february/tradoc_154243.pdf, (last visited May 12, 2016).

${ }^{136}$ Indian Ministry of New and Renewable Energy, Resolution, Jawaharlal Nehru National Solar Mission, No.5/14/2008-P\&C (Jan. 11, 2010), www.mnre.gov.in/solar-mission/jnnsm/resolution-2/; Indian Ministry of New and Renewable Energy, Jawaharlal Nehru National Solar Mission (July 23, 2015), http://pib.nic.in/newsite/PrintRelease.aspx?relid=123607.

${ }^{137}$ India Lodges WTO Appeal in US Solar Cells Dispute, INT'L CTR. FOR TRADE \& SUSTAINABLE DEV. (Apr. 28, 2016), www.ictsd.org/bridges-news/bridges/news/india-lodges-wto-appeal-in-us-solar-cells-dispute.

${ }^{138}$ See WTO Decision on Local Content Requirements Will Not Affect India Solar Ambitions, INT'L CTR. FOR TRADE \& SUSTAINABLE DEV. (Mar. 3, 2016), http://www.ictsd.org/bridges-news/biores/news/wto-decision-on-local-content-requirements-will-not-affect-india-solar.

${ }^{139}$ WTO: Dispute Settlement, India-Solar Cells - Certain Measures Relating to Solar Cells and Solar Modules, WTO Doc. DS456, https://www.wto.org/english/tratop_e/dispu_e/cases_e/ds456_e.htm. (last visited Apr. 10, 2017). 
- Meanwhile, India has lodged a WTO challenge against alleged LCRs and subsidies that eight U.S. states have imposed. ${ }^{140}$

Another contested trade-related issue is biofuels. Argentina and Indonesia together filed four WTO disputes regarding biodiesel anti-dumping duties imposed by the EU (notably, Argentina and Indonesia combined make up 90\% of the EU's biodiesel imports and capture over one-fifth of the market share). ${ }^{141}$ The main features of the four cases include the favoring of biodiesels produced in the EU by Spain; certain measures on importing and marketing of biodiesel; the support of the biodiesel industry in Belgium, France, Italy, Poland, and Spain; and anti-dumping measures within the EU. When challenging the EU policy under WTO law, Argentina and Indonesia referred to the Agreement Establishing the WTO and the GATT, TBT, TRIMS, Anti-Dumping, and SCM agreements. Whereas the dispute on the favoring of biodiesels produced in the EU by Spain was put on hold after Spain announced it would modify the biofuel rule, the panel report in the dispute on antidumping measures was published and is currently under review by the AB. ${ }^{142} \mathrm{In}$ the second dispute on anti-dumping measures, filed by Indonesia, the panel report is still pending. The dispute on the importation and marketing of biodiesel has not reached the panel stage (see Annex for further details).

\section{REGIONAL TRADE AGREEMENTS AND CLIMATE PROVISIONS}

Relevant rules on the climate-trade interface can also be found in RTAs. Three types of environmental and climate provisions exist. ${ }^{143}$ A first type is general environmental provisions that do not mention climate change, but are nevertheless applicable. They include references to the environment, references to principles of particular relevance to addressing climate change (e.g., the principle of common but differentiated responsibilities), provisions stipulating parties need to ensure a

140 WTO: Dispute Settlement, United States-Certain Measures Relating to the Renewable Energy Sector, WTO Doc. DS510, https://www.wto.org/english/tratop_e/dispu_e/cases_e/ds510_e.htm (last visited Apr. 10, 2017).

${ }^{141}$ WTO Pañel to Examine EU Duties on Argentine Biodiesel, INT'L CTR. FOR TRADE \& SUSTAINABLE DEV. (May 1, 2014), http://www.ictsd.org/bridges-news/bridges/news/wto-panel-to-examineeu-duties-on-argentine-biodiesel.

${ }^{142}$ EU, Argentina File Appeals in Biodiesel WTO Dispute, INT'L CTR. FOR TRADE \& SUSTAINABLE DEV. (June 2, 2016), http://www.ictsd.org/bridges-news/bridges/news/eu-argentina-file-appeals-inbiodiesel-wto-dispute.

${ }^{143}$ See Markus W. Gehring et al., Climate Change and Sustainable Energy in Regional Trade Agreements (RTAs): An Overview, INT'L CTR. FOR TRADE \& SUSTAINABLE DEV., ISSUE PAPER No. 3 (Aug. 2013), http:/www.ictsd.org/downloads/2013/08/climate-change-and-sustainable-energy-measuresin-regional-trade-agreements-rtas.pdf. 
high level of environmental protection, or instructing parties to uphold, improve, and enforce environmental laws. In addition, to the extent that references to multilateral environmental agreements are not specified (e.g., by listing them), any reference that specifies the relationship between an RTA and such agreements could also be seen to include the climate treaties (UNFCCC, Kyoto Protocol, Paris Agreement). The general environmental provisions also include specifications of the exception of Article XX of the GATT, with some RTAs extending the exception to other issue areas, such as technical barriers to trade.

A second type of provision explicitly aims at promoting or facilitating trade and investment in climate-relevant sectors. This includes provisions, among others, that specifically encourage the liberalization of trade in climate-friendly goods and services, provisions that could be aimed at removing non-tariff barriers (e.g. through harmonization of standards), and provisions that regulate energy subsidies. Several RTAs include provisions in which parties state their intentions to liberalize trade in environmental goods and services; including, for example, goods or services related to renewable energy.

The EU-Singapore Free Trade Agreement Article 13.11.2 ${ }^{144}$ is a recent example of this second type of agreement seeking to facilitate the trade in climatefriendly goods and services. In addition, Article 7.4(a) of the Agreement is dedicated to non-tariff barriers to trade and investment in renewable energy generation, in which it is specified parties will "refrain from adopting measures providing for local content requirements or any other offset affecting the other Party's products, service suppliers, investors or investments." 145 The same agreement also includes a provision on considering greenhouse gas emissions as reducing trade distortions from fossil fuel subsidies, stating "the Parties share the goal of progressively reducing subsidies for fossil fuels" contained in Article 13.11.3. ${ }^{146}$

A third type of provision, which can be found in many different RTAs, is aimed at deepening cooperation on climate change between the parties to the agreement. Such provisions include general commitments to enhance climate policy efforts and reaffirmations of existing commitments under the climate treaties. Also, provisions exist on a range of specific issues, including adaptation, carbon markets, technologies, forests, and agriculture. Depending on the mandate and, most importantly, budget allocations by the parties involved, such provisions can form the

144 EU-Singapore Free Trade Agreement, EUR. COMM'N art. 13.11 .2 (June 29, 2015), http://rade.ec.europa.eu/doclib/press/index.cfm?id=961.

${ }^{145} I d$. at art. 7.4(a).

${ }^{146} I d$. at art. 7.1. 
basis for subsequent technical cooperation, information exchange, and capacity building, and could even go beyond the commitments under the UNFCCC. ${ }^{147}$

\section{CLIMATE POLICY AND TRADE RULES: IDENTIFYING THE UPCOMING IS- SUES}

Following the Paris Agreement, the climate regime is intended to progress through the coordination of national action, its review, and adjustment over time. Climate policy decisions (e.g., targets, timelines, measures) are left with the parties to the Paris Agreement for the time being, with the agreement asking them to submit NDCs on a regular basis in the future. As Droege expounded, "[a]mong the many issues that require follow-up under the Paris Agreement, cooperation at the international level is planned with regard to the design of market and non-market mechanisms, finance, technology transfer, and the review and adjustment of NDCs." 148 Furthermore, no mandate was agreed on the international regulation of aviation and maritime transport. In this Part, we first look into international climate action inside and outside the auspices of the Paris Agreement regime (focusing on cooperative approaches, technology transfer, and sectoral policies for aviation and maritime transport), and then into national climate policy measures (focusing on carbon pricing and subsidies), with the goal of discussing the role of trade rules in promoting climate protection.

\section{A. COOPERATIVE APPROACHES}

The Kyoto Protocol introduced market-based, flexible mechanisms for its parties to help them deliver emission reductions in an economically efficient way through international emissions trading, the Clean Development Mechanism (CDM), and Joint Implementation (JI). The Paris Agreement has broadened the scope for using such mechanisms on a voluntary basis. However, it has left the design and implementation of these mechanisms unfinished, causing uncertainty about the future of the CDM, the new mechanisms, and the future rules on verifying and trading of yet-to-be defined emission rights under the UNFCCC from 2020 onwards. Given that roughly half of all INDCs submitted to date are "conditional

\footnotetext{
${ }^{147}$ See Peru-Korea Free Trade Agreement, ForeIGN TRADE INFO. SYs., at $§ 19.8 .2$ (signed Nov. 14, 2010), http://www.sice.oas.org/TPD/PER_KOR/PER_KOR_Texts_e/PER_KOR_ToC_e. asp (example of mutual commitment).

${ }^{148}$ Susanne Droege et al., The trade system and climate action: ways forward under the Paris Agreement, at 57 (Climate Strategies, Working Paper, Oct. 2016), http://climatestrategies.org/wp-content/uploads/2016/10/Trade-and-climate-ways-forward-1.pdf.
} 
upon having access to international carbon markets," 149 the importance of these provisions cannot be overstated, and despite the political divisions surrounding the concept of markets in the climate negotiations, parties expressly acknowledge the "important role of . . . tools such as . . . carbon pricing." "150

Article 6 of the Paris Agreement identifies various concepts for voluntary cooperative approaches to climate change mitigation. ${ }^{151}$ Two of these are relevant for future climate-trade interactions because they enable the emergence of markets in carbon units across national jurisdictions. Such approaches would not have to operate under rules developed under the Paris Agreement, but could be based entirely on domestic or regional market architectures. The Kyoto Protocol's flexible mechanisms (e.g., international emissions trading, CDM, JI) are not explicitly mentioned; Article 6.1 merely recognizes voluntary cooperative approaches as a means to implement NDCs, and all types of policy tools could fall under this declaratory provision. ${ }^{152}$ Articles 6.2 and 6.3 establish that cooperative approaches can result in "internationally transferred mitigation outcomes". ${ }^{153}$ Some elementary principles are set out in Articles 6.1 and 6.2, such as the need to ensure environmental integrity and transparency, robust accounting, and the avoidance of double counting. ${ }^{154}$ Guidance is to be "adopted by the Conference of the Parties serving as the meeting of the Parties to the Paris Agreement" ${ }^{155}$ It is widely expected such guidance will be limited to the creation of an accounting and transparency framework, while material criteria for the nature and stringency of carbon units will be defined at the domestic level. ${ }^{156}$

Article 6.4 establishes a "mechanism to contribute to the mitigation of greenhouse gas emissions and support sustainable development"157 (labelled by some as "sustainable development mechanism"). The negotiating history indicates this mechanism would bear resemblance to a baseline-and-credit system, such as

\footnotetext{
${ }^{149}$ Environmental Defense Fund \& the International Emissions Trading Association, Carbon Pricing: The Paris Agreement's Key Ingredient, InT'L EMISSIONS TrADING ASS'N, 1, 4 (2016), http://www.ieta.org/resources/Resources/Reports/Carbon_Pricing_The_Paris_Agreements_Key_Ingredient.pdf.

${ }^{150}$ U. $\bar{N}$. Framework Convention on Climate Change, Report of the Conference of the Parties on its twenty-first session, held in Paris from 30 November to 13 December 2015, supra note 28, at at 9 136.

${ }^{151}$ Paris Agreement, supra note 14, at art. 6.

${ }^{152} I d$. at art. 6.1.

${ }^{153} \mathrm{Id}$. at arts. 6.2, 6.3 .

${ }^{154} \mathrm{Id}$. at arts. 6.1, 6.2.

${ }^{155} \mathrm{Id}$. at art. 4.11 .

${ }^{156}$ See Christof Arens ed., The Dawning of a New Era, CARBOn MECHANISMS REV., Issue 1 (2016).

${ }^{157}$ Paris Agreement, supra note 14, at art. 6.4.
} 
the CDM under the Kyoto Protocol. ${ }^{158}$ Unlike the broader scope of cooperative approaches (i.e., Articles 6.2 and 6.3 of the Paris Agreement), the operation of a sustainable development mechanism would be subject to material and procedural control of the CMA, supervised by a body yet to be designated. ${ }^{159}$ Also, Article 6 opens the way for specific coalitions among countries who use emissions trading and who consider coordinating actions and rules, or even linking their systems. ${ }^{160}$

International trade in emission units is not an area of concern that has evolved under WTO or RTA rules, but was introduced with the Kyoto Protocol and subsequent rules under the UNFCCC. There are different views on whether emissions units would constitute goods under the GATT, or services under the GATS, while most commentators conclude that they are neither. ${ }^{161}$ By contrast, in-depth analyses are available for how regulations of national or supranational emissions trading systems, such as the inclusion of importers or free allocation rules, could contradict trade rules (see Part III.E). Greater agreement exists that services provided in the context of markets for different tradable climate-related units, for instance, greenhouse gas emission allowances, offset credits, or renewable energy and energy efficiency certificates in energy markets, fall under the GATS. ${ }^{162}$ These markets have seen robust growth, including a rise in the number of intermediaries (e.g., banks, brokers, exchanges, insurances, project developers, data providers, and verifiers). Some scholars disagree as to whether these services are covered by the GATS, and more specifically its Annex on Financial Services. ${ }^{163}$ Driven by the private sector, some primary markets for units have also given rise to secondary markets for derivative products, which expressly fall within the scope of the Annex on Financial Services. While some variability exists between individual Schedules

\footnotetext{
158 See See Andrei Marcu, CTR. FOR EUR. PoL'y Stud., Carbon Market Provisions in the Paris Agreement, 1, 13 (2016), http://www.ceps-ech.eu/sites/default/files/SR $\% 20$ No\%20128\%20ACM\%20Post $\% 20$ COP21\%20Analysis\%20of\%20Article\%206.pdf.

${ }^{159}$ Paris Agreement, supra note 14, at arts. 6.1, 6.3.

${ }^{160}$ Id. at art. 6; see also Arens, supra note 159, at 26-27.

${ }^{161}$ See, e.g., Joseph E. Aldy et al., Beyond Kyoto: Advancing the International Effort Against Climate Change Pew Ctr. on Global Climate Change (2003); N. Keohane, A. Petsonk \& A. Hanafi, Toward a club of carbon markets, Climatic CHANGE (2015); Annie Petsonk, The Kyoto Protocol and the WTO, 10 DUKE ENV'T L. \& POL'Y F. 185, (1999); Jacob Werksman, Greenhouse Gas Emissions Trading and the WTO, 8 REV. OF EuR., COMP. \& INT'L ENVTL. L. (1999).

${ }^{162}$ See James Munro, Trade in Carbon Units as a Financial Service under International Trade Law, 2 CARBOn \& Climate L. REV. 107 (1014); Marisa Martin, Trade Law Implications of Restricting Participation in the European Union Emissions Trading Scheme, 19 GEO. INT'L ENVTL. L. REV. 437 (2007); Glenn M. Wiser, The Clean Development Mechanism Versus the WTO, 11 GEO. INT'L ENVTL. L. REV. 531 (1999).

${ }^{163}$ See James Munro, supra note 165 (providing an overview of the continuing debate).
} 
of Commitments, ${ }^{164}$ a majority of members will have committed to exercise nondiscrimination subject to MFN, market access, and national treatment principles.

New issues could arise if emissions trading or carbon pricing coalitions ${ }^{165}$ emerged with rules that discriminate among WTO members; for instance, by excluding trade with non-parties or with parties based on the strength of respective emissions trading schemes (i.e., their environmental integrity). This has already been the case with the restricted fungibility of certain Kyoto Protocol units in the EU emissions trading system (ETS) based on their geographic origin (EU, 2009, Article 11a.4). ${ }^{166}$ If these issues were to arise, cooperative approaches could potentially come under the ambit of the trade regime if the entire rationale is premised on the ability to exclude non-members from a club benefit. ${ }^{167}$

\section{B. TRANSFER OF CLIMATE-FRIENDLY TECHNOLOGIES}

The need for technology transfer has been recognized in the UNFCCC (Article 4.5) and in the Paris Agreement (Article 10). The Paris Agreement emphasizes the means of implementation (e.g., finance, technology, and capacity building) must be provided by the industrialized countries to developing countries. However, the agreement does not prescribe how the transfer of climate-friendly technologies should be conducted, or how IPRs should be handled. ${ }^{168}$ This oversight is left to

\footnotetext{
${ }^{164}$ Over 100 members have entered commitments on financial services, and many apply an optional Understanding on Commitments in Financial Services annexed to the 1997 Financial Services Agreement, which became the GATS Annex on Financial Services. See generally WORLD TRADE ORGANIZATION AND WORLD BANK, I-TIP Services, http://i-tip.wto.org/services/default.aspx (last visited Apr. 11, 2017) (providing a database of Members' commitments under GATS and other trade agreements).

${ }^{165}$ See generally CARBOn Pricing LeadershiP COAL.., Leadership Coalition, http://www.carbonpricingleadership.org/leadership-coalition (last visited Apr. 11, 2017) (explaining the agenda of the coalition).

${ }^{166}$ [Citation for 2009 EU Emissions Trading System]. See generally Environmental Defense Fund $\&$ the International Emissions Trading Association, supra note 151, at 5-6 (interpreting Article 6 of the Paris Agreement); see generally Christina Voigt, WTO Law and International Emissions Trading: Is there Potential for Conflict?, CARBON \& ClimATE L. REV. 52 (2008) (providing an analysis under the Kyoto Protocol).

${ }^{167}$ See generally William Nordhaus, Climate Clubs: Overcoming Free-riding in International Climate Policy, 105(4) AM. ECON. REV. 1339 (2015) (noting without sanctions against non-participants, there are no stable coalitions other than those with minimal abatement. By contrast, a regime with small trade penalties on non-participants, a climate club, can induce a large stable coalition with high levels of abatement).

${ }^{168}$ See generally Padmashree G. Sampath \& Pedro Roffe, Unpacking the International Technology Transfer Debate: Fifty Years and Beyond (Int'l Ctr. for Trade \& Sustainable Dev., Working Paper ISSN 1684-9825, 2012) (explaining the history of the protection of IPRs).
} 
further negotiations under the auspices of the Paris Agreement and the WTO (including the TRIPS Agreement). Although 2010 UNFCCC talks in Cancún established a Technology Mechanism, the thorny issue of IPRs remains unaddressed. ${ }^{169}$

Sustained disagreement exists between developed and developing countries that are parties to the UNFCCC on the conceptualization of technology, its transfer process, and the effects from strong intellectual property protection. ${ }^{170}$ Proponents of strong intellectual property protection argue IPRs foster technology transfer by supporting the formation of contracts. ${ }^{171}$ However, as Ockwell and others opined, transnational companies are unlikely to deploy cutting-edge technologies they have spent significant resources on in those countries where they cannot ensure adequate IPR protection. ${ }^{172}$ Availability (and enforceability) of IPRs likely will not create a sufficient incentive for the transfer of technology. Rather, IPRs could make access to technologies more problematic by, for example, enabling the intellectual property right holder to keep prices prohibitively high. ${ }^{173}$

In addition, the variance in definitions of "technology" affect the applicability of trade rules. Contrastingly, technology transfer is best compared with the sale of a product because it includes capital-embodied technologies. ${ }^{174}$ Technology is not sold in its embodied form alone, nor is it fully codifiable.. ${ }^{175}$ Rather, it has tacit elements that are difficult or impossible to transfer in written forms. ${ }^{176}$ Instead,

\footnotetext{
${ }^{169}$ See Ahmed A. Latif et al., Overcoming the Impasse on Intellectual Property and Climate Change at the UNFCCC: A Way Forward, InT'L CTR. FOR TRADE \& SuSTAINABLE DeV., 1, 2-3 (2011) (postulating that IPRs have remained a constant source of controversy and disagreement).

${ }^{170}$ David G. Ockwell et al., Intellectual Property Rights and Low Carbon Technology Transfer: Conflicting Discourses of Diffusion and Development, 20(4) GloBAL EVTL. Change 729 (2010) [hereinafter Ockwell 2010].

${ }^{171}$ See, e.g., COMM'N ON GROwTH \& DEV., The Growth Report: Strategies for Sustained Growth and Inclusive Development (2008), http://siteresources.worldbank.org/EXTPREMNET/Resources/489960-1338997241035/Growth_Commission_Final_Report.pdf (noting without social contracts. sustaining the policies that promote growth is very difficult if not impossible); see, e.g., WORLD BANK, Global Economic Prospects: Technology Diffusion in the Developing World (2008), http://siteresources.worldbank.org/INTGEP2008/Resources/complete-report.pdf (2008) (stating taking issues without a contract to court takes a longer time as opposed to a contract dispute and thus hinders growth for technological companies).

172 Ockwell 2010, supra note 173, at 731.

${ }^{173} \mathrm{Id}$. at 730 .

${ }^{174}$ Sanjaya Lall, Understanding Technology Development, 24(4) DEV. \& CHANGE 719 (1993).

175 Sanjaya Lall \& Morris Tebual, “Market-Stimulating” Technology Policies in Developing Countries: A Framework with Examples from East Asia, 26 WORLD DEV. 1369, 1372 (1998).

${ }^{176}$ Jon Philipps et al, Governance and Technology Transfer in the Clean Development Mechanism in India, 23(6) GLOBAL ENVTL. CHANGE 1594, 1595 (2013).
} 
for transfers to be successful, technology must include learning via capability building. ${ }^{177}$ From this perspective, the intention of the importing party matters when addressing IPR protection: transfers enabling local competition against foreign suppliers will likely draw more attention to IPR issues than if the buyer does not assimilate the technology. Firms holding IPRs are more likely to apply rights to prohibit access if there is assimilation and that leads to increased competition. ${ }^{178}$

The TRIPS Agreement plays an important role when countries discuss the future handling of IPRs for traded climate-friendly technologies. ${ }^{179}$ The TRIPS Agreement provides countries and firms with flexibility on how to protect their IPRs, as well as affords special treatment for the least developed countries. ${ }^{180} \mathrm{How}-$ ever, it does not resolve disputes over the strength and enforcement of IPRs or provide a uniform definition of technologies. Considering international trends that have emerged over the last twenty years, strengthening IPRs under the TRIPS Agreement will need to be addressed to help quell economic concerns. ${ }^{181}$

In 2010, the WTO published an overview for policy makers, identifying the relevant standards of the TRIPS Agreement for climate negotiations. ${ }^{182}$ Patents are the most important IPR issue within the climate context, but the WTO addresses other IPR tools as well (e.g., trademarks, plant variety rights, certification marks). ${ }^{183}$ Additionally, joining the debate in the 2011 WTO CTE, China and India made a joint submission-both underscoring that IPRs must not become a barrier

\footnotetext{
${ }^{177}$ Kasturi Das, Technology Transfer under the Clean Development Mechanism: an Empirical Study of 1000 CDM Projects (The Governance of Clean Dev., Working paper No. 014, 2011).

178 See Adrian Lema \& Rasmus Lema, Technology Transfer in the clean development mechanism: Insights from wind power, 23 GLOBAL ENVTL. CHANGE 301 (2013) (discussing licensing in the wind power industry);

Joanna I. Lewis, Technology Acquisition and Innovation in the Developing World. Wind Turbine Development in China and India, 42 STUD. IN COMP. INT'L DEV. 208(2007) (examines how two leading developing-country firms have acquired and assimilated advanced technologies provides crucial insights into facilitating competition).

179 See Ockwell 2010, supra note 173.

180 Antony Taubman \& Jayashree Watal, The WTO Trips Agreement - A Practical Overview for Climate Change Policymakers, Intellectual Property Division of the WTO, 1, 14 (2010).

${ }^{181}$ David Ockwell, Intellectual property rights and low carbon technology transfer to developing countries - a review of the evidence to date,

UK-INDIA COLLABORATION TO IDENTIFY THE BARRIERS TO THE TRANSFER OF LOW CARBON ENERGY TECHNOLOGY (2008), https://www.sussex.ac.uk/webteam/gateway/file.php?name=spru-teriids-phase-2-iprs-and-low-c-tt-final.pdf\&site $=264$.

182 Taubman \& Watal, supra note 185.

183 Scott Barrett, Rethinking Global Climate Change Governance, 3(5) ECON. E-J. 1 (2009), http://www.economics-ejournal.org/economics/journalarticles/2009-5.
} 
to the transfer of environmentally sound technologies. ${ }^{184}$ In 2013 , Ecuador also made a similar claim in a TRIPS Council submission, joining the ranks of countries seeking to combat climate change. ${ }^{185}$

\section{GLOBAL SECTORAL POLICIES: AVIATION AND MARITIME TRANSPORT}

The most prominent unresolved global mitigation challenges arise from aviation and shipping activities. The emission sources, airplanes and marine vessels, provide cross-border services and partly operate in international spaces beyond the sovereign territory of individual states. Given the unique territorial and jurisdictional operations, the climate regime has largely excluded aviation and maritime shipping. They were subject to UNFCCC negotiations, but the Paris Agreement does not mention these international emission sources. The Kyoto Protocol, on the contrary, expressly stated in its Article 2.2 that any relevant action on emissions from international aviation and marine bunker fuels should occur through the International Civil Aviation Organization (ICAO) and the International Maritime Organization (IMO). ${ }^{186}$ After the slow pace of international negotiations and continued rapid growth of aviation and shipping emissions, the EU announced it would include international aviation in its emissions trading system from 2012 onwards. ${ }^{187}$ This unilateral action against globally operating sectors led to significant tensions ${ }^{188}$ and the EU subsequently suspended its measure under intense international pressure. This move helped revive negotiations under the ICAO and the IMO. ${ }^{189}$ These organizations struggle with discord about the necessity, design, and economic consequences of measures to limit aviation and shipping emissions, strong pressure from industry groups, as well as asymmetrical interests of coalitions of

\footnotetext{
184 Third World Network, Proposal: Contribution of Intellectual Property to Facilitating the Transfer of Environmentally Rational Technology, IP/C/W/585 3 (Feb. 27, 2013), http://www.twn.my/title2/climate/info.service/2013/climate130602.htm.

185 Alexandra Bhattacharya, WTO discusses intellectual property and green technologies transfer, THIRD WORLD NETWORK (Feb 28, 2014), http://www.twn.my/title2/climate/info.service/2014/cc140201.htm.

${ }^{186}$ Kyoto Protocol, supra note 5.

187 European Commission, Reducing emissions from aviation (Oct. 4, 2017), http://ec.europa.eu/clima/policies/transport/aviation en.

${ }^{188}$ Susanne Dröge \& Philipp M. Richter, Emissionshandel fuer den Luftverkehr, 55 STIFTUNG WISSENSCHAFT \& POLITIK (2012) (title translated: Emission trading in aviation. This article discusses the international tensions that arose from the EU including international aviation in its ETS).

${ }^{189}$ See Sarabjett Hayer, Decision-making processes of ICAO and IMO in respect of environmental regulations, POLICY DEP'T A: ECON. \& SCI. POL'Y (2016), http://www.europarl.europa.eu/RegData/etudes/STUD/2016/595332/IPOL_STU(2016)595332_EN.pdf (Both organizations have been exploring the issue, through the ICAO's Environment Branch and the IMO's Marine Environment Protection Committee respectively; the 39th Session of the ICAO Assembly in September/October 2016 is expected to result in adoption of a market-based measure to limit aviation emissions).
} 
states (including disagreement about applying differential treatment to developing countries).

The role of the trade regime is limited as well. The GATS Agreement offers only little guidance in two annexes on air and maritime transport services. ${ }^{190}$ Under the "Annex on Air Transport Services," aviation generally is excluded from the substantive scope of the GATS (exceptions are aircraft repair, maintenance services, selling and marketing of air transport services, and computer reservation system services). ${ }^{191}$ For shipping, the corresponding "Annex on Negotiations on Maritime Transport Services" states MFN treatment only applies following the conclusion of additional negotiations on maritime transport services within the WTO. ${ }^{192}$ However, under the of 28 June 1996 decision, the Council for Trade in Services suspended the maritime transport negotiations until the commencement of the next comprehensive round of services negotiations, ${ }^{193}$ which are still ongoing.

At its 39th Session in September and October 2016, the ICAO Assembly adopted an international market-based measure to limit aviation emissions, designated a "Carbon Offsetting and Reduction Scheme for International Aviation" (CORSIA). ${ }^{194}$ Under this scheme, any growth in $\mathrm{CO}_{2}$ emissions from international aviation above 2020 levels will have to be compensated through the purchase and surrender of offset credits. During an initial pilot phase from 2021 to 2023 and the first implementation phase from 2024 to 2026, the scheme will apply only to airlines from states voluntarily opting to participate in CORSIA; starting with the second phase from 2027 to 2035, however, all states will be covered, except certain least developed countries and small island developing nations. The ICAO scheme CORSIA will not supersede any existing treaty-based trade commitments between ICAO members under the legal principle of lex posterior derogat legi priori. Still, the

190 WTO, The General Agreement on Trade in Services: An Introduction, (Jan. 31, 2013), https://www.wto.org/english/tratop_e/serv_e/gsintr_e.pdf.

${ }^{191} I d$. at 4 .

192 WTO, Annex on negotiations on maritime transport services, https://www.wto.org/english/tratop_e/serv_e/11-anmar_e.htm (last visited Apr. 11, 2017).

${ }^{193}$ Decision on Maritime Transport Services, WTO Doc. S/L/24 (July 3,1996).

${ }^{194}$ International Civil Aviation Organization, Environmental protection - International Aviation and Climate Change - Policy, Standardization and Implementation Support, A39-WP/462 (2016), http://www.icao.int/Meetings/a39/Documents/WP/wp_462_en.pdf. For general discussion, see generally Alejandro Piera, Compliance Tools for a Global Market Based Measure for Aviation. Designing the Legal Form of a Global Aviation Market Based Measure, 2 CARBON \& ClimATE L. REV. (2016). 
outcome and consensus it reflects can have a significant bearing on the interpretation of Article XX GATT when defending trade-restrictive climate measures, especially where these apply to the transport sector and international spaces.

\section{INDCS: ARE THERE POLICY MEASURES WITH TRADE IMPLICATIONS?}

In 2015, 188 parties to the UNFCCC submitted their INDCs. The INDCs are diverse and do not follow a particular formula. Countries were free to announce their climate policy targets, measures, or conditionalities, such as financial demands for adaptation and mitigation. Trade implications from INDCs arise for all measures that tax, subsidize, or regulate national economic activities, which relate directly or indirectly to other countries' participation in trade. As the WTO disputes (see Part II.C) demonstrate, national energy policy measures increasingly cause concerns about unfair competition. Local content requirements or other standards, as well as anti-dumping measures and countervailing duties, can be in conflict with trade law. These requirements are used in national legislations (e.g., programs to foster the provision of renewable technologies and production), and are rooted in national approaches to industrial policy making.

In 92 out of 162 INDCs, ${ }^{195}$ the intention of using international market mechanisms is indicated, while 45 do not mention this tool at all. ${ }^{196}$ Mostly low-income countries intend to sell some type of mitigation unit to source carbon finance flows - provided such a trading option materializes under Article 6 of the Paris Agreement. However, there currently is only a small number of countries willing to buy such units (e.g., Japan, Norway, Switzerland, Turkey). Some countries express their interest in using international market mechanisms in the future (29), while others explicitly reject them (18). ${ }^{197}$ The INDCs so far reveal many countries intend to address emissions through investment in renewable energy. Some countries lay out detailed policy intentions. Most parties have announced relative or absolute targets

\footnotetext{
195 See generally, United Nations Framework Convention on Climate Change, INDCs as communicated by Parties, http://www4.unfccc.int/submissions/indc/Submission\%20Pages/submissions.aspx (last visited Apr. 11, 2017) (The EU INDC consists of one submission comprising 28 EU Member States, even though the total number of parties that have submitted INDCs by Jun. 2016 was 190).

196 See Nicolas Kreibich \& Wolfgamg Obergassel, Carbon Markets After Paris: How to Account For Transfer of Mitigation Results, JIKO Policy Paper (Nov. 12, 2016) ). See also Environmental Defense Fund \& the International Emissions Trading Association, supra note 151, at 6.

${ }^{197}$ Nicolas Kreibich, Wuppertal Institute, presentation at 16th Climate Technology Workshop (Jun. 23-24 2016).
} 
(e.g., India: wind power installation of $60 \mathrm{GW}$, solar power of $100 \mathrm{GW}$ by 2022 ; China: increasing the share of non-fossil fuels to $15 \%$ of energy consumption by 2020 and to $20 \%$ by 2030 ; EU: $40 \%$ greenhouse gas emission reductions until 2030 , no details on energy targets). ${ }^{198}$

Given the high profile of the NDCs in the Paris Agreement, the national approaches could be increasingly exposed to scrutiny by trade partners, but will also set the stage for international exchange on policy practice. In this context, the absence of guidance regarding how the Paris Agreement implementation relates to the trade regime could become a critical issue in the future, and this could lead to a high profile of the forum on the impacts of the implementation of response measures (see Part I.A).

\section{E. NATIONAL AND REGIONAL CARBON PRICING: EMISSIONS TRADING AND CAR- BON TAXES}

The debate on the trade implications of national climate policy started with the Kyoto Protocol and carbon pricing in industrialized countries. ${ }^{199}$ From a climate economics perspective, there are two basic ways to foster mitigation. First, domestic policy can focus on supporting clean technologies; for example, renewable energy production. Market stimulation via increased returns on investment and reduction in non-market barriers will help foster major technological breakthroughs. Secondly, governments can introduce policies that raise costs for producers who emit carbon dioxide. For example, governments can use an explicit carbon price-like a carbon tax or a greenhouse gas emissions trading system, or they can use implicit technology regulation - as performance standards. Carbon dioxide producers can curb increased costs by creating a cost pass-through to customers, investing in cleaner technologies, or decreasing production. A carbon producer competing against producers located in countries with little or no climate policy tools-all other things equal - are at a competitive disadvantage. ${ }^{200}$ Thus, illustrating how ineffective unilateral carbon pricing or regulation may be amongst competitors. Therefore, if domestic demand shifts to cheaper imported products, then production

\footnotetext{
${ }^{198}$ See generally Su Wei, Enhanced Actions On Climate Change: China's Intended Nationally Determined Contributions (2015), http://www4.unfecc.int/Submissions/INDC/Published\%20Documents/China/1/China's\%20INDC\%20-\%20on\%2030\%20June\%202015.pdf.

${ }^{199}$ See, Pauwelyn, U.S. Federal Climate Policy and Competitiveness Concerns, supra note 70, at 2; Cosbey et al. 2009, supra note 79, at 3; Susanne Droege, Tackling Leakage in a World of Unequal Carbon Prices, Climate STRATEGIES (2009), http://www2.centre-cired.fr/IMG/pdf/cs_tackling_leakage_report_final.pdf.

200 Carolyn Fischer, Options for avoiding carbon leakage, 3, http://voxeu.org/sites/default/files/file/fischer.pdf (last visited Apr. 11, 2017).
} 
abroad increases and causes more emissions, offsetting the domestic mitigation in other countries (also known as "carbon leakage").

To avoid carbon leakage, both at the border measures and behind the border, measures are available. ${ }^{201}$ For example, if imported goods fell under the importing countries' carbon pricing policy (i.e., tax or emissions allowances coverage), the carbon leakage effect is reduced at the border. Policies implemented in this manner are referred to as border carbon adjustments (BSA). BCAs can work in two wayspricing imports and reimbursing exports - and resemble border tax adjustments, which commonly are applicable under consumption taxes (such as value added tax). Additionally, a BCA could include rebates to exporters, helping alleviate disadvantages in international markets. ${ }^{202}$ The introduction of a BCA measure has been explored in the $\mathrm{EU}^{203}$ and in the US (in the unsuccessful American Clean Energy and Security Act of 2010, as well as in the proposed American Opportunity Carbon Fee Act of 2014). ${ }^{204}$ Next, for companies who compete internationally, a behindthe-border policy could include tax exemptions or other payments to help alleviate increased costs. However, under an emission trading systems, allocation of emission certificates — based on output (past or current) - would also provide an avenue to ease the cost of purchasing allowances.

Two basic designs exist for developing BCA measures. One option is to establish a BCA aligned with the requirements under Article III $^{205}$ for domestic policy tools (following several criteria under Article II.2(a) of GATT, which apply to a legal border tax adjustment ${ }^{206}$ ). A second option is to design a BCA in such a

\footnotetext{
${ }^{201} I d$. at 8 .

${ }^{202}$ See, Cosbey et al. 2009, supra note 79, at 17; Cosbey et al., Developing Guidance for Implementing Border Carbon Adjustments, REV. OF ENVTL. ECON. \& POL'Y (forthcoming 2016) [hereinafter Cosbey et al. 2016].

${ }^{203}$ See Lorand Bartels, The WTO Legality of the Application of the EU's Emission Trading System to Aviation, 23/2 EUR. J. OF INT’L L. 429-467 (2012); Droege \& Richter, supra note 194, at 1-2 (2012); Harro van Asselt \& Thomas Brewer, Addressing Competitiveness and Leakage Concerns in Climate Policy: An Analysis of Border Adjustment Measures in the US and the EU, 38/1 ENERGY POL'Y 47-49 (2010).

${ }^{204}$ See, Madison Condon \& Ada Ignaciuk, Border Carbon Adjustment and International Trade: A Literature Review, (OECD Trade and Environment Working Papers, 2013); see, e.g., Roland Ismer $\&$ Karsten Neuhoff, Border Tax Adjustment: A Feasible Way to Support Stringent Emission Trading, 24/2 EUR. J. OF L. \& ECON. 140 (2007); Pauwelyn, U.S. Federal Climate Policy and Competitiveness Concerns, supra note 70, at 8-9. See generally, van Asselt \& Brewer, supra note 214, at 42-51; Sam Kortum \& David Weisbach, Border Adjustments for Carbon Emissions: Basic Concepts and Design, Resources for the Future (2016); GARY Clyde HufBaUer ET AL., Global WARMING AND THE WORLD TRADING SYSTEM (2009).

${ }^{205}$ GATT, supra note 21 , at Art. III.

${ }^{206}$ Id. at Art. II.2(a).
} 
way that it passes the tests of Article XX GATT ${ }^{207}$ and qualifies for an exception. ${ }^{208}$ The design choice is key for creating BCA measures that are consistent with WTO rules. Because considerable uncertainty of WTO jurisprudence exists ${ }^{209}$ and introduction of BCAs will compound legality questions, implementing these types of measures is less desirable. ${ }^{210}$ The environmental purpose of a measure that violates the non-discrimination obligations has to be clearly established through its design and practical implementation. ${ }^{211}$ Most importantly, it must not serve the protection of domestic industries. ${ }^{212}$ Thus, a BCA, at the very least, has to refer to the carbon content of a traded good and it has to target carbon leakage reduction.

The free allocation of allowances to companies and the indirect or direct payments to compensate for carbon costs could be problematic from a trade policy point of view, too, especially if such allowances tend to overcompensate the actual cost impact. If allowances tend to overcompensate, then the policy may result in subsidisation and could be challenged under WTO rules (notably the SCM Agreement). ${ }^{213}$ While this situation is speculative, it has a strong link to the disputes over subsidies for renewable energy.

\section{F. ENERGY SUBSIDIES}

Subsidies play an important role in implementing the Paris Agreement through NDCs for two reasons: 1) subsidies are applied to foster renewable energy investments and production; and 2) existing subsidies for fossil fuels provide incentives for the production and consumption of carbon-intensive fuels. Subsidies for the production and consumption of both low- and high-carbon energy can serve a variety of non-climate policy objectives, such as protecting or building up industrial sectors to secure or promote employment, poverty alleviation, and increasing

\footnotetext{
${ }^{207}$ Id. at Art. XX.

${ }^{208}$ Cosbey et al., supra note 79 , at 10-11.

${ }^{209}$ See Carrie Wofford, A Greener Future at The WTO: The Refinement of WTO Jurisprudence on Environmental Exception to GATT, 24 HARV. ENVTL. L. REV. 563, 563-64 (2000).

${ }^{210}$ Kasturi Das, Climate Club: Carrots, Sticks and More, ECON. \& Pol. WeEkLy 24-26 (Aug. 22, 2015).

${ }^{211}$ See Cosbey et al. 2016, supra note 213, at 8-9 (per footnote fifteen: In WTO case law, the legality of exceptions depended on the actual implementation (targeted goods, targeted countries of origin), or the consideration of multilateral solutions to an environmental problem (US-Shrimp case Appellate Body). In the EU-Asbestos Case (DS135: European Communities - Measures Affecting Asbestos and Asbestos-Containing Products), the discriminatory impact of a trade measure applied to a "like" imported product was seen to depend on its competitive relationship to the domestic product).

${ }^{212}$ See, Ludivine Tamiotti, The Legal Interface between Carbon Border Measures and Trade Rules, 11 Climate Pol'y 1202, 1208-09 (2011).

${ }^{213}$ See, SCM supra note 40; see generallyWTO, Anti-dumping, subsidies, safeguards: contingencies, etc, supra note 119.
} 
the security of energy supply. These objectives can collide with trade rules. ${ }^{214}$ Depending on the scope, design, and application of subsidies, unintended adverse socio-economic and environmental effects can be significant. For instance, the International Energy Agency suggests consumption subsidies were responsible for $13 \%$ of global carbon dioxide emissions in 2014 (equivalent to a subsidy of US \$115 per tonne of carbon dioxide). ${ }^{215}$

The general relationship between the WTO and energy is not straightforward: the complex characteristics of energy and energy markets distinguishes energy from other traded goods regulated by the international trading system. Energy can be both a good or a service, meaning it is governed by different WTO rules simultaneously, including, but not limited to, the SCM Agreement.

Although trade disputes have focused largely on renewable energy subsidies (see Part II.C), such rules in theory also apply to fossil fuel subsidies. Subsidies contingent upon export performance or upon the use of domestic over imported goods are prohibited under WTO law; however, other subsidies deemed "specific" (i.e., aimed at certain enterprises or industries) and lead to adverse effects for other members are actionable, meaning they are subject to a challenge. ${ }^{216}$ Furthermore, the SCM Agreement specifies WTO members should notify their subsidies, providing sufficient details to allow other members to assess the impacts on trade. ${ }^{217}$ Applying these rules in practice, however, has proven difficult. In contrast to renewable energy support, no fossil fuel subsidy has ever been challenged by a WTO member before the WTO dispute settlement system. ${ }^{218}$ For consumer subsidies, a key challenge is to prove such subsidies are "specific," given that the benefits of such subsidies generally accrue to a broad group of producers, consumers, or both. ${ }^{219}$ More importantly, however, notification rates of subsidies have generally

\footnotetext{
${ }^{214} I d$.

${ }^{215}$ International Energy Agency, Energy \& Climate Change, WorLd ENERGY OUTLOOK SPECIAL REPORT 23 (2015), https://www.iea.org/publications/freepublications/publication/WEO2015SpecialReportonEnergyandClimateChange.pdf.

216 WTO, Agreement on Subsidies and Countervailing Measures ("SCM Agreement"), https://www.wto.org/english/tratop_e/scm_e/subs_e.htm (last visited Feb. 18, 2017) (WTO explanation and overview of the SCM agreement, explaining the procedure of determining the categorization of subsidies).

${ }^{217} I d$.

${ }^{218} \mathrm{Cf}$. Rowland, Legal Challenge to Government’s $£ 2.5 B N$ Subsidy Scheme for Fossil Fuel Industry, Roseacre Awareness Group (Dec. 6, 2017), http://www.ragfrack.co.uk/legal-challenge-governments-2-5bn-subsidy-scheme-fossil-fuel-industry/ (noting, in regard to judicial proceedings brought before national or regional courts, the United Kingdom was challenged under European Union law for a fossil fuel subsidy).

${ }^{219}$ See, e.g., Henok Birhanu Asmelash, Energy Subsidies and WTO Dispute Settlement: Why Only Renewable Energy Subsidies Are Challenged, 18/2 J. OF INT'L ECON. L., 261, 269-70 (2015).
} 
been low due to a lack of commitment (possibly due to fear of starting a trade dispute), lack of clarity about which subsidies need to be reported, and the inherent difficulties of estimating them. ${ }^{220}$ Even if WTO members do report subsidies, the surveillance mechanism rarely leads to the questioning of the subsidies. ${ }^{221}$

\section{SOLUTIONS: HOW THE TRADE REGIME COULD SUPPORT CLIMATE AC- TION}

There are many suggestions regarding to find sustainable solutions to reduce conflicts between the trade and the climate regimes, including the conversion of the legal rules of the WTO and RTAs into a set of obligations supporting climate policy objectives. However, given the reduced interest in the Doha Round negotiations, the prospects for legal reform are bleak. Therefore, this Part not only identifies reform options, but also refers to processes that would enable a more pragmatic way forward in the absence of legal reform. In our evaluation of options, we consider if and how more certainty can be created by a suggested solution, and if the suggested change is more likely in the short term or in the longer term.

We consider the following areas for supporting international and national climate policy by trade rules and regimes. First, there could be explicit specifications and reforms on how the two regimes relate to each other, both under the WTO and in RTAs (Part IV.A). Second, supporting trade rules for climate policy measures could be established for specific issues with a focus on the Paris Agreement's implementation (Part IV.B). Third, institutional cooperation could be intensified in several ways (Part IV.C).

\section{A. GENERAL RELATIONSHIP BETWEEN CLIMATE AND TRADE REGIMES}

\section{ADDRESSING THE CLIMATE-TRADE OVERLAP THROUGH CHANGES IN THE WTO AGREEMENTS}

Legal guidance to clarify the relationship between WTO rules and climate policy measures is not easily achievable. One argument in favor of reforming WTO rules is the case-by-case nature of WTO disputes does not provide sufficient structural legal guidance for the implementation of NDCs under the Paris Agreement, and leaves the settlement of climate-related disputes to a body that is guided first

${ }^{220}$ See Casier et al., supra note 117, at 19 (2014).

221 See Ronald Steenblik \& Juan Simón, A New Template for Notifying Subsidies to the WTO, GLOBAL SUBSIDIES INITIATIVE 8 (2011), http://www.globalsubsidies.org/files/assets/_template_ for_notifying_subsidies_to_the_WTO.pdf. 
and foremost by the rules of the multilateral trading system. ${ }^{222}$ If the demand for legal guidance increases, such guidance can only be provided by the WTO members. $^{223}$ There are several ways in which demands for legal services can meet this need.

A first option is to amend WTO agreements to change the relevant trade rules. Suggestions in this regard include amending Article XX of GATT to explicitly accommodate climate change measures or measures taken pursuant to multilateral environmental agreements, or amending the SCM Agreement to provide space for green subsidies. ${ }^{24}$

From a legal perspective, an ambitious reform of the legal framework through amendments or new rule creation would be attractive. It would increase the legal certainty and normative coherence across regimes, and offer a solution for the long term. ${ }^{225}$ However, it is far from clear what the content of such rules would have to be to serve both climate and trade aims. And even if there was clarity about the contents of an amendment, negotiating an amendment will be very challenging. Submitting an amendment already requires consensus, and depending on the contents of the amendment (and the specific treaty provision it applies to), it will require at least a two-thirds majority of members accepting it, and in some cases, all members. ${ }^{226}$ Amendments may also lead to a complex legal situation - in which not all members are bound in the same way-if a sufficient number, but not all, of the WTO members accept it. ${ }^{227}$ Finally, practically speaking, amendments have hardly been used in WTO practice so far. ${ }^{228}$

\footnotetext{
222 See James Bacchus, Global Rules for Mutually Supportive and Reinforcing Trade and Climate Regimes, E15 EXPERT GrP. On Measures to AdDress Climate Change \& THE TRAde Sys. (2016), http://www3.weforum.org/docs/E15/WEF_Climate_Change_POP.pdf. See also EPPS \& GREEN, supra note 109, at 260, 265 (providing details about the discussion how the WTO regime and dispute settlement should better take into account non-trade concerns).

${ }^{223}$ See generally, Ludivine Tamiotti, The legal interface between carbon border measures and trade rules, CLIMATE POL'Y 1027 (2011) (noting “there are a vast number of views expressed by academics, policy-makers, and various stakeholders on ... the extent to which [measures (economic, technical, regulatory, and others that may overlap between environment and trade rules) taken by members to mitigate climate change] are consistent with WTO rules.")

${ }^{224}$ See Climate Change Justice \& Human Rights Task Force, InT'l Bar Ass'N, Achieving JustiCE AND HUMAN RIGHTS IN AN ERA OF CLIMATE DisRUPTION 166-67 (2014).

${ }^{225}$ See Harro van Asselt et al., Global Climate Change and the Fragmentation of International Law, 30 LAW \& POL'Y 440 (2008).

${ }^{226}$ See Agreement Establishing WTO, supra note 32, at art. X.

227 See id.

${ }^{228}$ See Beatriz Leycegui \& Imanol Ramirez, Addressing Climate Change: A WTO Exception to Incorporate Climate Clubs, E15 EXPERT GRP. ON MEASURES TO ADDRESS ClIMATE CHANGE \& THE
} 
A second option is to waive specific WTO obligations for a limited time. Waivers, which can be adopted if there are "exceptional circumstances," 229 require a three-fourths majority, although consensus has remained the rule in practice. ${ }^{230}$ Examples for existing waivers include regional economic integration or justification of non-reciprocal trade preferences for products from developing countries. ${ }^{231}$ A WTO member could argue achieving climate policy objectives constitutes "exceptional circumstances." A specific and far-reaching suggestion is made by Bacchus, who suggests a waiver from WTO obligations for all trade-restrictive climate measures that are based on the amount of carbon used in making a product. ${ }^{232}$ This, for example, would be applicable to BCAs. He further suggests a waiver for measures taken in furtherance of a UNFCCC climate agreement (e.g., the Paris Agreement) or a plurilateral "climate club." ${ }^{233}$ A key question requiring clarification is how to define the scope of the waiver, i.e., what are the actual "climate measures." 234

The time-limited nature of waivers suggests a waiver will not create longterm certainty. At the same time, the temporary nature of a waiver might render it more appealing than a permanent amendment. Feichtner points out a waiver allows for a general modification of WTO norms in the direction of non-economic interests. ${ }^{235}$ More precisely, it restricts the WTO jurisdiction in favor of "other international legal regimes which may have greater competence and legitimacy than the WTO to deal with certain issues," ${ }^{236}$ and which actually have a legal mandate that affects trade. ${ }^{237}$ If waivers were used repeatedly, this could also create a long-term effect for consideration of climate policy issues under the WTO. Again, the limitations to introducing a waiver are set by the political interests in doing so. If the

TRADE SYS., 3 (2015), http://www.ictsd.org/sites/default/files/research/E15_Climate_Leycegui\%20and\%20Ramirez FINAL.pdf. (noting, "The only amendment decision in the WTO was passed in 2005, which modified the TRIPS Agreement. In ten years, the decision has been accepted in only 53 local legislatures of the total 160 WTO Members.").

${ }^{229}$ See Agreement Establishing WTO, supra note 32, at art. IX.3.

${ }^{230}$ See HUfBAUER ET AL., supra note 215, at 97. See also Leycegui \& Ramirez, supra note 240, at 2.

${ }^{231}$ See WTO Director-General, WTO Annual Report 200818 (2016), https://www.wto.org/english/res_e/booksp_e/anrep_e/world_trade_report08_e.pdf. .

${ }^{232}$ See BACCHUS, supra note 234, at 15.

${ }^{233}$ See id. ("Climate clubs" could be integrated in the trade-and-climate regimes through RTAs (meaning the members to an RTA extent their cooperation on climate policy), or through the WTO plurilateral agreements under Annex 4 (see Part IV.A.1)).

${ }^{234}$ See EPPS \& GREEN, supra note 109 , at 255-56.

${ }^{235}$ See Isabel Feichtner, The Waiver Power of the WTO: Opening the WTO for Political Debate on the Reconciliation of Competing Interests, 20 THE EUR. J. OF INT’L L. 615, 618 (2009).

${ }^{236} \mathrm{Id}$. at 645.

${ }^{237}$ See id. at 618. 
implementation of NDCs under the Paris Agreement would bring about structural issues that increase the pressure for waiving specific climate policy measures, the tool could offer a way forward, but it would not resolve structural, long-term conflicts.

A third option is to adopt an authoritative interpretation of certain provisions in the WTO Agreements by a three-fourths majority (Article IX.2 of the Agreement Establishing the WTO), although also here consensus is the rule in practice. ${ }^{238}$ Buck and Verheyen suggest members could agree certain regulations based on a product's PPMs (e.g., how much emissions are embedded in a product) would not violate the GATT, and this would effectively settle questions about the legality of PPMs. ${ }^{239}$ The far-reaching nature of this suggestion limits its political feasibility in practice. However, an authoritative interpretation could offer an alternative to implement the suggestions for amendment - albeit with weaker legal force — such as clarifying the scope of Article XX of GATT. ${ }^{240}$ Another suggestion is a declaration that climate measures taken pursuant to the Paris Agreement (or with reference to the UNFCCC) are measures within the scope of Article XX of the GATT and of Article XIV of the GATS. ${ }^{241}$

The introduction of an authoritative interpretation of Article XX of GATT is less of an intervention in the regime than an amendment or a waiver. An authoritative interpretation would set a clear frame for the interpretation of Article XX and thus would document consensus among WTO members on the importance of climate-related policies under the WTO regime. It would mainly affirm existing opinio juris around Article XX GATT, but by being explicit it could deter judicial action by opponents to specific climate action. ${ }^{242}$

There are also downsides to authoritative interpretations. If an authoritative interpretation is very broad, for example referring to the Paris Agreement or to the NDCs in general, this could give a carte blanche for the protectionist application

\footnotetext{
238 See Claus-Dieter Ehlermann \& Lothar Ehring, The Authoritative Interpretation Under Article IX:2 of the Agreement Establishing the World Trade Organization: Current Law, Practice, and Possible Improvements, 8 J. OF INT'L ECON. L. 803, 806 (2005).

239 BUCK \& VERHEYEN, supra note 108.

240 See Climate Change Justice \& Human Rights TASK ForCE, supra note 236, at 166.

${ }^{241}$ See BACCHUS, supra note 234, at 16 (referring to an agreement under the UNFCCC).

242 See WTO, United States - Standards for Reformulated and Conventional Gasoline, https://www.wto.org/english/tratop_e/dispu_e/cases_e/ds2_e.htm_(last visited Apr. 12, 2017). See also WTO, India - Certain Measures Relating to Solar Cells and Solar Modules, https://www.wto.org/english/tratop_e/dispu_e/cases_e/ds456_e.htm_(last visited Apr. 12, 2017) (discussing the role of Article XX-see Table 1 in Annex 1);

[Bartels (2012), p.
} 494;] 
of trade policy tools, given that climate action depends on national preferences and is subject to changing agendas and priorities. In addition, an authoritative interpretation cannot make non-trade rules directly applicable in a trade dispute. However, it could help tilt the balance towards a climate-friendly interpretation of certain provisions of the WTO Agreements.

Another way to give some leeway for WTO members when implementing their climate policies under the Paris Agreement would be a time-limited "peace clause" for taking action against trade-related climate measures. ${ }^{243}$ "[A] peace clause could commit WTO members to wait at least three years before challenging national climate measures or [refrain from using] countermeasures that restrict trade or otherwise have trade effects in WTO dispute settlement." 244 A comparable clause had been in effect for nine years with respect to agricultural subsidies. ${ }^{245}$ Hufbauer et al. suggest a similar clause could be used which focuses particularly on climate-related subsidies, though in principle such a clause could be used for any climate-related trade measure. ${ }^{246}$

Alternatively, as suggested also by Hufbauer et al., a peace clause could commit states not to implement climate measures with extraterritorial implications, such as a BCA. ${ }^{247}$ This may be helpful in creating trust and goodwill. It may also be helpful for other countries affected to start gearing up for the measure.

As with waivers, the challenge for a peace clause is to get the scope right. In other words, the challenge is to single out those measures that legitimately seek to implement the Paris Agreement or otherwise promote climate goals. If one can get the scope right, a peace clause would buy time that could be used for constructive dialogue rather than further confrontation over specific issues. ${ }^{248}$ Otherwise, a conflict only gets postponed and would return after the peace clause expires. ${ }^{249}$ The same argument applies if a peace clause hinders the reform of ineffective climate policy practices, such as generous free allocation of emission allowances under an ETS. $^{250}$

\footnotetext{
${ }^{243}$ See HufBAUER ET AL., supra note 215, at 109. See also BACCHUS, supra note 234, at 14.

244 BACCHUS, supra note 234, at 14.

${ }^{245}$ See generally WTO, Agriculture Negotiations: Backgrounder Phrase 1: The peace clause, https://www.wto.org/english/tratop_e/agric_e/negs_bkgrnd13_peace_e.htm (last visited Apr. 12, 2017).

246 See HUFBAUER ET AL., supra note 215, at 109, 110.

247 See, e.g., EPPS \& GREEN, supra note 109, at 253; HUFBAUER ET AL., supra note 215, at 100.

248 See HUFBAUER ET AL., supra note 215 at.103-10 (referring to the contested issue of BCA).

${ }^{249}$ See EPPS \& GREEN, supra note 109, at 254.

250 See BACCHUS, supra note 234, at 17.
} 
An ill-formulated peace clause could also potentially offer countries a carte blanche, and thus create a perverse incentive for introducing protectionist or otherwise trade-restrictive climate policy measures. ${ }^{251}$ A peace clause ultimately requires amendment of the relevant WTO agreements, and is therefore subject to the same limitations as other amendments.

A fourth option suggests adjustments to the WTO dispute settlement mechanism. Proposals exist to expand the jurisdiction of the WTO DSB to non-trade rules and principles, which could give climate obligations further weight as compared to free trade disciplines in WTO judicial decision making. However, such proposals are not likely to gain traction in the short term. A more feasible proposal would be to ensure that the composition of WTO panels and the AB as such reflect the necessary technical expertise to cover climate-related issues (e.g., supporting the determination of whether a certain policy measure effectively contributes to greenhouse gas emission reductions).

Finally, acknowledging the challenges of consensus, Hufbauer et al. propose a plurilateral trade and climate code to deal with a range of aspects on the climate-and-trade interface. ${ }^{252}$ They propose this code could be adopted as a plurilateral agreement under Annex 4 of the WTO Agreement (similar to, for example, the Government Procurement Agreement). Similarly, ICTSD has suggested a "Sustainable Energy Trade Agreement," covering not only the liberalization of climate-friendly goods and services, but also non-tariff barriers such as technical standards. ${ }^{253}$ A plurilateral agreement would not create rights or obligations for other WTO members, but its inclusion in Annex 4, which would allow for enforcement of the agreement through the WTO's dispute settlement mechanism, does require consensus. ${ }^{254}$ The benefits of such an agreement would normally accrue to all WTO members to the extent that it covered subjects within the scope of the MFN obligations of WTO agreements. ${ }^{255}$ Thus, on the one hand, the negotiation of an agreement inside the WTO system is easier due to the lower number of parties, but on the other hand, its approval as an additional Annex 4 agreement requires the agreement of all WTO members.

\footnotetext{
251 See EPPS \& GREEN, supra note 109, at 253.

${ }^{252}$ GARY ClYDE HUfBAUER ET AL, supra note 215 at, 103.

${ }^{253}$ ICTSD, supra note 43 at 14 (2011).

${ }^{254}$ Michitaka Nakatomi, Plurilateral Agreements: A viable alternative to the WTO?, WTO (Mar. 11, 2013), https://www.wto.org/english/res_e/reser_e/wts_future2013_e/Nakatomi.pdf.

${ }^{255}$ Matthew Kennedy, Legal Options for a Sustainable Energy Trade Agreement, INT'L CTR. FOR TRADE \& SUSTAINABLE DEV. 1, 8-10, http://www.ictsd.org/downloads/2012/07/legal-options-fora-sustainable-energy-trade-agreement.pdf.
} 
Such a plurilateral agreement under the WTO does not necessarily bring about more complexity - the GPA, for example, does not yield this effect. The limited-membership arrangement would be open to participation by further WTO members and could thus expand its membership over time. The EGA negotiations - limited to traded goods - demonstrate plurilateral agreements may offer a way forward to promote common interests among groups of WTO members. Plurilateral climate-and-trade cooperation could also take place outside the context of the WTO regime. However, this option would exacerbate the fragmentation of the trade regime.

\section{ADDRESSING THE CLIMATE-TRADE OVERLAP THROUGH CHANGES IN RTAS}

RTAs have already demonstrated environmental standards could become part of a trade agreement. RTAs could potentially further promote climate objectives in two ways. First, the negotiation of new types of provisions could lead to synergies with climate goals, and prevent a race to the bottom. Parties to an RTA have an interest in keeping up their national standards, because otherwise trade partners could quickly gain competitiveness through lowering standards. Thus, RTAs can be more detailed and more elaborate in setting common rules for trade-related climate measures, in particular by aligning standards and regulations. To ensure compatibility with WTO rules, it would be important for parties of an RTA to pay due regard to standards from third countries. ${ }^{256}$ In addition, dispute settlement rules and consultations could consistently relate to climate policy concerns, such as concerns regarding provisions on investment, which usually regulate whether and how an investor may challenge a country's climate regulations through investor-state dispute settlement. ${ }^{257}$ Two overarching options to promote climate protection can be distinguished with regard to investment. First, parties could preserve the flexibility for climate regulation. This could include narrowing down or clarifying key concepts in international investment agreements - such as "indirect expropriation" or the "fair and equitable treatment" standard - as well as extending exceptions (or creating new ones) to investment, removing climate regulations from the scope of investor-state dispute settlement. Second, parties could agree on provisions encouraging low-carbon investment. These could include low-carbon performance

\footnotetext{
${ }^{256}$ Kateryna Holzer and Thomas Cottier, Addressing Climate Change under Preferential Trade Agreements. Towards Alignment of Carbon Standards under the Transatlantic Trade and Investment Partnership, Global EnVtl. Change, 514, 515 (2015).

${ }^{257}$ See, e.g., Daniel M. Firger \& Michael B. Gerrard, Harmonizing Climate Change Policy and International Investment Law: Threats, Challenges and Opportunities, in YEARBOOK ON INTERNATIONAL INVESTMENT LAW \& POLICY 2010-2011 1, 1-2 (Karl P. Sauvant, ed., 2011).
} 
requirements for investors. ${ }^{258}$ Such provisions, however, need to be balanced against the objectives to attract and promote investment.

If RTAs were to develop in this direction, they would hold the potential to facilitate multilateral agreements on climate-trade interactions in the longer term. The extent to which this potential can be realized depends on the parties to the RTA. The greater the market power of the parties negotiating specific standards, the greater the likelihood that such standards will be taken up elsewhere. Other countries may do this on a unilateral basis, through the inclusion of standards in a greater number of RTAs, and ultimately, through multilateralization via the WTO. ${ }^{259}$ There is thus a crucial role for the mega-regional agreements at a time of lower interest in rule development through the WTO. Bilateral agreements, such as the EU-Singapore Free Trade Agreement, do not have this leverage. Nevertheless, these smaller agreements can inject new ideas into the debate. As negotiations on mega-regionals, such as TTIP are, ongoing, this offers an opportunity to facilitate trade in climate-friendly technologies between the US and the EU, and furthermore, ensure regulatory coherence, including aligning standards. Other issues could be included as well, such as strengthening environmental laws and enforcement, and further promoting collaboration on climate-related issues, such as fossil fuel subsidy reform. ${ }^{260}$

Thus, RTAs could support climate policy measures through codifying standards and aligning rules among trade partners; by clarifying investment rules and related dispute settlement provisions; and by functioning as a clearing house for other trade and climate related issue areas.

\section{B. ADDRESSING THE CLIMATE-TRADE OVERLAP THROUGH CHANGES IN RULES ON SPECIFIC ISSUES}

The following discusses the prospects of reform for specific issues on the trade-climate interface, focusing on emissions trading and carbon pricing, energy subsidies, and technology transfer and intellectual property rights.

\footnotetext{
258 Id. at 2.

259 See Holzer \& Cottier, supra note 268, at 515.

${ }^{260}$ Ingrid Jegou, Sonja Hawkins, \& Kimberley Botwright, What role for trade and investment in the new climate regime?, INT'L CTR. FOR TRADE \& SUSTAINABLE DEV. (Feb. 19, 2016), http://www.ictsd.org/bridges-news/biores/news/what-role-for-trade-and-investment-in-the-newclimate-regime.
} 


\section{EMISSIONS TRADING AND CARBON PRICING}

Detailed rules for the international transfer of mitigation outcomes under Article 6 of the Paris Agreement have yet to be elaborated. Past research on the flexible mechanisms of the Kyoto Protocol and domestic market-based instruments already indicated how mechanisms under Article 6 might intersect with international trade law. ${ }^{261} \mathrm{~A}$ critical point relates to restrictions on the fungibility of carbon units based on criteria such as geographic origin (as applied to CDM credits under the EU ETS). This could limit the ability of service providers to supply services related to ineligible units that would be considered like services related to eligible units, thus creating a conflict with GATS rules. This issue could be resolved with one or more of the reform options discussed above (Part IV.A); for example, with an authoritative interpretation that restrictions on carbon units fall within the scope of Article XIV of the GATS.

For the introduction of BCAs, there are two routes to establish a clearer legal status. First, the design of BCAs can follow the non-discrimination principle of Article III of GATT and the requirements for an internal tax. Second, if BCAs do not follow Article III of GATT in their setup, the Article XX criteria need to be applied, which demand that all alternative measures that are least trade-restrictive are exhausted. Article XX also demands that diversion from national treatment, based on non-product-related PPMs - here, embedded carbon - relates to preventing ineffective climate policy (carbon leakage). The implementation of NDCs through national carbon pricing could bring back the discussion on specific rules on BCA. For the time being, these two WTO routes could be explored if governments wished to use BCAs. As the tool is politically highly sensitive, due to its protectionist potential, clearer codes of conduct would be helpful as well if its consideration as part of NDC implementation became relevant. In particular, the introduction of BCAs would need to evaluated in the light of a WTO member's antileakage policies already in place, such as free allocation of emission allowances.

${ }^{261}$ See, e.g., Keohane, Petsonk \& Hanafi, supra note 164, at 185; Werksman, supra note 164, at 251; G.M. Wiser, The Clean Development Mechanism Versus the World Trade Organization: Can Free-market Greenhouse Gas Emissions Abatement survive Free Trade?, 11 GEO. ENVTL. L. REV. $531,531$. 


\section{ENERGY SUBSIDIES}

In response to the issues raised by renewable energy subsidies, reform of WTO subsidy rules has been suggested, as well as the introduction of new agreements on the promotion of renewables. ${ }^{262}$ On the one hand, the case law of WTO disputes over renewable energy policy implementation might offer guidance on how a productive balance could be found between a national agenda to promote renewable energy and international competition concerns. On the other hand, the WTO agreements cited in the disputes comprise the GATT, the Anti-Dumping, TBT, TRIMS and SCM agreements, indicating conflicts with trade rules are profound. Local content requirements are a common feature of the disputes, and this should not be surprising. Renewable energy production can yield several benefits that a domestic government aims for, including increasing employment. Such industrial policy objectives are not covered by trade law, and solving the conflicts by changing the trade rules is not recommendable, given that protectionism can be a serious concern of trade partners. Thus, the legal reform options-e.g., amendment, waiver, peace clause, or authoritative interpretation ${ }^{263}$ — would need to offer a solution that rules out their protectionist abuse. More detailed reform suggestions in this direction include the creation of a category of narrowly defined non-actionable subsidies - a positive list of support instruments and related design featuresto change the categories of subsidies under the SCM Agreement, or to establish disciplines for certain subsidies that are not covered yet. ${ }^{264}$

Given the lack of clarity on fossil fuel subsidies, an important first step would be to enhance the transparency of such subsidies; for instance, by adopting a new notification template providing further details on subsidies in a standardized fashion $^{265}$ and allowing non-governmental organizations to report on the level of

\footnotetext{
${ }^{262}$ See Ilaria Espa \& Sonia E. Rolland, Subsidies, Clean Energy, and Climate Change, E15 TASK FORCE ON RETHINKING INT'L SUBSIDIES DISCIPLINES 5 (Feb. 2015), https://e15initiative.org/wpcontent/uploads/2015/09/E15-Subsidies-EspaRolland-FINAL.pdf .

263 See e.g. Robert Howse, Securing Policy Space for Clean Energy under the SCM Agreement: Alternative Approaches, E15 EXPERT GROUP ON CLEAN ENERGY TECHNOLOGIES \& THE TRADE SYSTEM (Dec. 2013) 5, http://e15initiative.org/wp-content/uploads/2015/09/E15-CETs-Howse-Final.pdf; see also Ricardo Meléndez-Ortiz, Enabling the Energy Transition and Scale-Up of Clean Energy Technologies: Options for the Global Trade System, E15 EXPERT GROUP ON CLEAN ENERGY TECHNOLOGIES AND THE TRADE SYSTEM 7 (Jan. 2016), http://www3.weforum.org/docs/E15/WEF_Clean_Energy_Technologies_report_2015_1401.pdf (an authoritative interpretation of Article XX $\bar{X}$ outreach and application to the SCM Agreement).,.

${ }^{264}$ See Gary Horlick \& Peggy A. Clarke, Rethinking Subsidy DisCIPLINES FOR THE FutURE E15 TASK FORCE ON RETHINKING INT'L SUBSIDIES DisCIPLINES 5-7 (Jan. 2016), http://e15initiative.org/wp-content/uploads/2015/09/E15_no18_Subsidies_final_REV_x1.pdf.

${ }^{265}$ Steenblik and Simón supra note 233, at 9.
} 
non-actionable subsidies. ${ }^{266}$ Neither of these options would require changes in the WTO's legal framework. Further incentives for reform could arise if a fossil fuel subsidy would qualify as either "prohibited" or "actionable," 267 meaning other WTO members can take action under the SCM Agreement, or if such subsidies could be challenged under the GATT or the TRIMS Agreement in the same way renewable energy subsidies have been challenged. However, at present it seems quite unlikely WTO members are willing to renegotiate the subsidies regime to take into account the climate impacts of fossil fuel subsidies. Although there has been progress in other areas of environmentally harmful subsidies, namely fisheries, the stakes are significantly higher in the case of fossil fuel subsidies, ${ }^{268}$ given the sheer size of such subsidies and given that almost every country in the world provides them.

\section{TECHNOLOGY TRANSFER AND INTELLECTUAL PROPERTY RIGHTS}

The resolution of the different interpretation of IPRs and the different concepts of intellectual property are often claimed as being the biggest hurdle for climate technology transfer, leaning on the examples of pharmaceuticals or defense technologies. Suggestions for a reconciliation of the concerns, like the one submitted by Ecuador in 2013, include modification of IPR rules or a declaration on intellectual property and climate change in line with Doha Declaration on the TRIPS Agreement and Public Health. The key aspect is the interpretation of TRIPS Articles 13 and 30 (use of patents), for which a waiver or an authoritative interpretation had been suggested. ${ }^{269}$ However, any solution needs to incorporate the concerns of both developing and developed countries, which will take a longer period of time. The debate at TRIPS Council on IPRs protection and interpretation will continue. Promoting climate protection is already a need that is integrated in the debate. The underlying conflicts about IPRs however, block solutions to specific aspects of protection of climate technology and know-how. The chances of resolving IPR issues

\footnotetext{
266 See Casier et al. supra note 117, at 12-13.

267 See C. Wold et al., Leveraging Climate Change Benefits through the World Trade Organization: Are Fossil Fuel Subsidies Actionable?, 43 GEO. J. OF INT'L L. 587, 656-57 (2012), pp. 656-657 (indicating it would be very difficult for one member to prove that another member's subsidy causes an "injury"); but see Horlick \& Clarke, supra note 276, at 10 (considering fossil fuel subsidies as "actionable").

268 Sadeq Bigdeli, Will the "Friends of Climate" Emerge in the WTO? The Prospects of Applying the "Fisheries Subsidies" Model to Energy Subsidies, 2 CARBON \& Climate L. REV., 80.

${ }^{269}$ See Ahmed Abdel Latif et al., , Overcoming the Impasse on Intellectual Property and Climate Change at the UNFCCC: A Way Forward, InT'L CTR. FOR TRADE \& SuSTAINABLE DEV. 1, 36-37 (Nov. 2011), http://www.ictsd.org/sites/default/files/research/2012/02/overcoming-the-impasseon-intellectual-property-and-climate-change-at-the-unfccc-a-way-forward.pdf.
} 
seem bleak given the highly political nature of the debate, and the vested interests that dominate decision making.

\section{WAYS FORWARD: ACCOUNTING FOR THE POLITICAL LANDSCAPE}

Given the hurdles to reform the WTO regime, or to align it with climate measures that are part of the Paris Agreement, other options should be considered that could bring about a more supportive role of the trade regime. Politically more promising are options that integrate the procedures of the climate and trade institutions, and deepen the existing procedural arrangements.

\section{IMPROVING THE INSTITUTIONAL SETTING}

Procedural reform could start with greater use of existing forums under the WTO and the UNFCCC as coordination hubs that actively engage parties on climate and trade issues. There is already informal interaction between the UNFCCC Secretariat and the WTO members and institutions - in particular, the CTE. A first step in that direction could include upgrading the roles for the Trade Policy Review Mechanism, and the CTE of the WTO, as well as the Subsidiary on Body Scientific and Technological Advice (SBSTA) of the UNFCCC. The Trade Policy Review Mechanism could be strengthened to include a compulsory assessment of the impact of relevant domestic measures on emissions and efforts to address climate change. ${ }^{270}$ In addition, decision-making and administrative bodies in both the trade and climate regimes could seek to actively liaise in a systematic way, strengthening their knowledge base, and creating a better understanding of the implications of trade-climate interactions for the respective objectives, principles, and legal obligations in each regime.

To address interactions, Epps and Green suggest the introduction of a separate WTO Committee on Trade and Climate Change. ${ }^{271}$ As an alternative option, the mandate of the CTE could be explicitly extended to include climate change policy, turning it into a Committee on Trade, Environment, and Climate Change. If this proves to be a feasible option for the WTO members to address trade-related climate policy issues in more detail, such a Committee on Trade, Environment, and Climate Change could include representatives from WTO members with distinct knowledge of UNFCCC issues.

\footnotetext{
270 See BACCHUS, supra note 234, at 16.

${ }^{271}$ EPPS \& GREEN, supra note 109, at 261.
} 


\section{INCREASING TRANSPARENCY THROUGH NOTIFICATION AND REVIEW}

To improve the flow of information around climate measures that affect international trade or have the potential to do so, notification of such measures could be introduced in a formal manner; for example, by including in future NDC submissions to the UNFCCC a section that highlights trade-related aspects of specific national climate actions. Another option that could provide information also for the WTO committees would be to introduce at the UNFCCC Secretariat an information hub through the creation of a central registry. Parties to the UNFCCC could $\log$ and record trade-related climate measures, or even include such information in the transparency template guiding countries in their mandatory reporting under the Paris Agreement. Such notifications can be sensitive. However, enhanced transparency is key for building trust between developing, emerging, and industrial countries. The notification of trade-related climate measures could be linked to the work program of the UNFCCC improved forum on the impacts of the implementation of response measures. Addressing trade issues in the forum will undoubtedly be challenging - as it has been in the past - but the more technical turn of the forum's new work program may offer space for less politicized discussions.

For specific issues, such as fossil fuel subsidies, and policies to promote renewable energy, the notification to the SCM Committee would help increase the transparency on such measures. For issues that touch upon GATS legality, the evaluation of the classification of environmental services in the WTO Committee on Trade in Services could be undertaken. This could aim at extending the WTO services classifications, with a view to coordinating negotiations on environmental goods trade with negotiations on related services, ultimately opening the door for greater legal certainty on climate-related services under the GATS.

\section{CONCLUSIONS}

The trade and the climate regimes have so far co-existed without severe frictions. With the recent emergence of a number of climate-related disputes and the Paris Agreement's emphasis on nationally driven mitigation, the interactions between the policy fields could increase. Both regimes find themselves at a crossroads. This might lead to new opportunities to create rules and procedures that support trade-related climate policy measures.

The climate regime has been considering trade-related aspects over the years of negotiations. The Paris Agreement, however, in contrast to the UNFCCC and the Kyoto Protocol, does not include a provision stating how climate policy and trade rules relate to each other. Parties to the Paris Agreement have agreed 
instead to continue discussions on trade-related issues under the heading of response measures.

The WTO provisions can conflict with climate protection measures, if such measures discriminate between domestic and foreign goods, based on the processes and production methods involved. The likeness of goods and the equal treatment of WTO members are key features of the WTO's non-discrimination regime. However, there are also exceptions for the pursuit of environmental objectives.

The WTO Agreements are increasingly put to the test by national climate policies that seek to promote renewable energy production and new technologies, or by conflicts over international IPR protection for clean technologies. Complications arise due to an increasing breadth of climate-related technologies trade and related services. WTO case law, while acknowledging the need for climate protection, sets clear signals against overly protectionist ways to support climate-friendly industrial strategies - foremost in conflicts over national renewable energy promotion. The WTO dispute settlement bodies have been sensitive to environmental issues, but they continue to encounter criticism from traditional trade interests. Thus, WTO members clearly signalling that dispute settlement must take climate protection seriously, would benefit the panels and the AB.

Regional trade deals hold potential to show that countries anticipate the conflicts in promoting climate protection through standards and industrial policy. RTAs are more flexible in meeting the engaged partners' political priorities. Thus, a benefit of the trend towards RTAs and mega-regional trade deals could be that climate policy objectives are given proper attention.

The Paris Agreement will, over time, give rise to further questions in relation to trade. One issue concerns the market mechanisms and trading of international emission reduction units. The potential of trade rules impeding the exchange of emission units seems low given the experiences under the Kyoto Protocol. Rather, related services (especially related to financial markets) need to be more clearly defined under the GATS. Another issue is the future treatment of imports and exports based on their PPMs. Such questions are more likely to come to the fore once targets and associated policies become more ambitious, and with the emergence of new coalitions to price carbon. BCAs have attracted political attention in the past already, and their application could become of interest again when national climate policies are strengthened. The expectation is national policies on: pricing emissions, energy production (including renewables and fossil fuels support), and on fostering specific technologies via trade will need to be coordinated with trade policy aims, thus putting demands on the institutions of the climate and the trade regimes. 
With more ambitious NDCs expected in the future, the trade-related climate measures will remain in the spotlight. The specific IPR issues need to be resolved, and talks under the TRIPS Agreement as well as rules in RTAs are key components of progress in this field. The adjustment of restrictive trade-related IPRs is a highly political matter, and this will dominate further negotiations under the WTO as well as the Technology Mechanism of the UNFCCC. Last, but not least, the reduction of fossil fuel subsidies will need more support from international institutions, including the WTO, as their impact on climate change is considerable.

We conclude by highlighting five particular ideas for how the trade rules and negotiations could become more supportive for climate protection:

1. The WTO legal reform options lack political support. Nevertheless, we see an authoritative interpretation of Article XX (b) and (g) of the GATT, as well as its chapeau, as a way forward in the longer term. This could clarify the scope of exceptions to trade obligations, and it could also offer an important political signal that the WTO is open to accommodating the climate policies of its members. An authoritative interpretation would need to focus on issues that either have already been agreed through the WTO dispute settlement procedures or are likely to be commonly agreed.

2. The dispute settlement system under the WTO could be made more supportive for the Paris Agreement's implementation. For example, more climate expertise could be made part of the WTO dispute settlement processes. Article 13 of the WTO's Dispute Settlement Understanding, as well as several other WTO agreements, already give the dispute panels the right to seek information and technical advice from experts - provided, of course, the relevant rules and procedures are followed. It is necessary to make use of this window as effectively and extensively as possible.

3. The negotiations of RTAs are a promising way forward for introducing and testing new rules on climate and trade. In particular, the so-called megaregional trade deals have a potential to diffuse climate protection rules more widely, as long as the negotiating parties have a common interest in avoiding a race to the bottom in setting climate protection standards.

4. Plurilateral trade agreements that are incorporated as WTO agreement (Annex 4 WTO Agreement) would offer a more WTO-specific option to set rules for trade and climate policy. WTO members who wish to bring environmental protection forward have already started the Environmental Goods Agreement. A broader trade and climate agreement, covering specific climate policy issues (e.g., market mechanisms, services, and non-tariff barriers), could further strengthen the promotion of climate protection through trade by progressive WTO members. 
5. The bodies of the WTO and the UNFCCC could increase transparency and accountability. To this end, an extended institutional setting at the WTO, for instance through a Committee on Trade, Environment, and Climate Change, would be an option. The UNFCCC Secretariat already has observer status with the CTE. Furthermore, the UNFCCC Secretariat is often also invited to the Special Sessions of the CTE on a meeting-by-meeting basis. However, there is still scope for increasing the coordination of existing bodies at the WTO (e.g., the CTE and the Trade Policy Review Mechanism) and the UNFCCC (Subsidiary Body on Scientific and Technological Advice, and the forum on the impact of the implementation of response measures). The aim should be a regular and elaborated exchange of information on NDC implementation.

\section{REFERENCES}

Asmelash, H. B. (2015), 'Energy Subsidies and WTO Dispute Settlement. Why Only Renewable Energy Subsidies Are Challenged', Journal of International Economic Law, 18/2: 261-285.

Bacchus, J. (2016), Global Rules for Mutually Supportive and Reinforcing Trade and Climate Regimes, ICTSD and World Economic Forum, E15 Expert Group on Measures to Address Climate Change and the Trade System < http://www3.weforum.org/docs/E15/WEF Climate Change POP.pdf>.

Baldwin, R. E. (1997), 'The Causes of Regionalism', World Economy, 20/7: 865-888.

— (2014), Multilateralising $21^{\text {st }}$ Century Regionalism, OECD, Global Forum on Trade $<\underline{\text { https: } / /}$ www.oecd.org/tad/events/OECD-gft-2014-multilateralising-21st-century-regionalism-baldwinpaper.pdf>.

Barrett, S. (2009), 'Rethinking Global Climate Change Governance', Economics E-Journal, 3/5: 112.

Bartels, L. (2012), 'The WTO Legality of the Application of the EU's Emission Trading System to Aviation', European Journal of International Law, 23/2: 429-467.

Bhagwati, J. (1992), 'Regionalism versus Multilateralism', World Economy, 15/5: 535-556.

Bigdeli, S. Z. (2008), "Will the "Friends of Climate" Emerge in the WTO? The Prospects of Applying the "Fisheries Subsidies" Model to Energy Subsidies', Carbon \& Climate Law Review, 2/1: 78-88.

Bodle, R., Donat, L., and Duwe, M. (2016), The Paris Agreement: Analysis, Assessment and Outlook, Umweltbundesamt, Background Paper for the Workshop "Beyond COP21: What Does Paris Mean for Future of Cimate Policy?" < $\underline{\text { http://ecologic.eu/sites/files/event/2016/ecologic institute }}$ 2016 paris_agreement_assessment_0.pdf $>$.

Böhringer, C., Balistreri, E. J., and Rutherford, T. F. (2012a), 'The Role of Border Carbon Adjustment in Unilateral Climate Policy. Overview of an Energy Modeling Forum study (EMF 29)', Energy Economics, 34: 97-110.

Böhringer, C., Carbone, J. C., and Rutherford, T. F. (2012b), 'Unilateral Climate Policy Design. Efficiency and Equity Implications of Alternative Instruments to Reduce Carbon Leakage', Energy Economics, 34: 208-217.

Buck, M., and Verheyen, R. (2001), International Trade Law and Climate Change - A Positive Way Forward, Friedrich-Ebert Stiftung, FES-Analyse Ökologische Marktwirtschaft $<\underline{\text { http://li- }}$ brary.fes.de/pdf-files/stabsabteilung/01052.pdf $>$. 
Carpenter, T. (2009), ‘A Historical Perspective on Regionalism', in P. Low and R. E. Baldwin (eds.), Multilateralizing Regionalism (Cambridge: Cambridge University Press), 13-27.

Casier, L., Fraser, R., Halle, M. et al. (2014), 'Shining a Light on Fossil Fuel Subsidies at the WTO. How NGOs Can Contribute to WTO Notification and Surveillance', World Trade Review, 13/4: 603-632.

Chan, N. (2016), 'The 'New' Impacts of the Implementation of Climate Change Response Measures', Review of European, Comparative and International Environmental Law, 25/2: 228237.

Charnovitz, S. (2003), 'Trade and Climate: Potential Conflicts and Synergies', in Pew Center on Global Climate Change (ed.), Beyond Kyoto: Advancing the international effort against climate change, 141-170 <http://www.c2es.org/docUploads/Beyond\%20Kyoto.pdf $>$.

Commission on Growth and Development (2008), The Growth Report: Strategies for Sustained Growth and Inclusive Development $<$ http://siteresources.worldbank.org/EXTPREMNET/Resources/489960-1338997241035/Growth_Commission_Final_Report.pdf $>$.

Condon, M., and Ignaciuk, A. (2013), Border Carbon Adjustment and International Trade: A Literature Review, OECD, OECD Trade and Environment Working Papers, 2013/06 < http:// www.oecd-ilibrary.org/docserver/download/5k3xn25b386c.pdf?expires $=1473154807 \& \mathrm{id}=\mathrm{id} \&$ accname $=$ guest \&check$\underline{\text { sum }=19004 \text { C9147C561A9E70145481D522F5A }>\text {. }}$

Cosbey, A. (2008), Border Carbon Adjustment, International Institute for Sustainable Development, Background Paper $<\underline{\mathrm{https}} / / / \mathrm{www}$. iisd.org $/ \mathrm{pdf} / 2008 / \mathrm{cph}$ trade climate border carbon.pdf $\mathrm{s}$.

Cosbey, A., Droege, S., Fischer, C. et al. (2012), A Guide for the Concerned: Guidance on the Elaboration and Implementation of Border Carbon Adjustment, Entwined, Policy Report, No. 3 $<$ http://www.iisd.org/pdf/2012/bca_guidance.pdf $>$.

Cosbey, A., Droege, S., Fischer, C. et al. (2016), 'Developing Guidance for Implementing Border Carbon Adjustments', Review of Environmental Economics and Policy, forthcoming.

Das, K. (2011), Technology Transfer under the Clean Development Mechanism: an Empirical Study of 1000 CDM Projects, University of East Anglia and ESRC Economic \& Social Research Council, The Governance of Clean Development: Working Paper Series $<\underline{\text { http://papers.ssrn.com/sol3/ }}$ papers.cfm? abstract id $=1887727>$.

- (2015), 'Climate Clubs: Carrots, Sticks and More', Economic \& Political Weekly, 50/34.

_ (2016), 'Policy Space for Clean Energy and the Global Trade Governance under WTO: India Solar Dispute and beyond', Conference Proceedings, XUB Sustainability Summit 2016: Energy, Peace and Global Governance, Xavier School of Sustainability, Xavier University Bhubaneswar, India.

Delimatsis, P., and Mavromati, D. (2009), 'GATS, Financial Services and Trade in Renewable Energy Certificates (RECs) - Just Another Market-based Solution to Cope with the Tragedy of Commons', in T. Cottier, O. Nartova, and S. Z. Bigdeli (eds.), International Trade Regulation and the Mitigation of Climate Change. World Trade Forum (Cambridge: Cambridge University Press), 231-58.

Droege, S. (2009), Tackling Leakage in a World of Unequal Carbon Prices, Climate Strategies $<$ http://www2.centre-cired.fr/IMG/pdf/cs tackling_leakage report final.pdf $>$.

(2011), 'Using Border Measures to Address Carbon Flows', Climate Policy, 11/5: 1191-1201.

Dröge, S., and Richter, P. M. (2012), Emissionshandel für den Luftverkehr: Internationaler Widerstand gegen den Alleingang der EU, German Institute for International and Security Affairs, SWP Comments, No. $55<$ https://www.swp-berlin.org/fileadmin/contents/products/aktuell/ 2012A55 dge richter.pdf $>$.

Eckersley, R. (2009), 'Understanding the Interplay between the Climate and Trade Regimes', in B. Simmons, H. van Asselt, F. Zelli et al. (eds.), Climate and Trade Policies in a Post-2012 World (Geneva: UNEP), 11-18. 
EDF, and IETA (2016), Carbon Pricing: The Paris Agreement's Key Ingredient <http://carbonpulse.com $/ 18680 /$ ?utm source $=\mathrm{CP}+$ Daily\&utm campaign $=26 \mathrm{c} 5149 \mathrm{ef6}-$ CPdaily21042016\&utm medium =email\&utm term $=0$ a9d8834f72-26c5149ef6-110242833 >.

Ehlermann, C.-D., and Ehring, L. (2005), 'The Authoritative Interpretation under Article IX. 2 of the Agreement Establishing the World Trade Organization: Current Law, Practice and Possible Improvements', Journal of International Economic Law, 8/4: 803-824.

Epps, T., and Green, A. (2010), Reconciling Trade and Climate: How the WTO Can Help Address Climate Change (Cheltenham: Edward Elgar).

Espa, I., and Rolland, S. E. (2015), Subsidies, Clean Energy, and Climate Change, E15 Initiative, Think Piece < http://e15initiative.org/wp-content/uploads/2015/09/E15-Subsidies-EspaRollandFINAL.pdf $>$.

European Commission (2013), General Overview of Active WTO Dispute Settlement Cases Involving the EU as Complainant or Defendant and of Active Cases under the Trade Barriers Regulation, European Commission <http://trade.ec.europa.eu/doclib/docs/2007/may/tradoc 134652.pdf>, accessed 12 May 2016.

— (2016), The European Union's Measures Against Dumped and Subsidised Imports of Solar Panels from China. <http://trade.ec.europa.eu/doclib/docs/2015/july/tradoc 153587.pdf>.

Feichtner, I. (2009), 'The Waiver Power of the WTO. Opening the WTO for Political Debate on the Reconciliation of Competing Interests', European Journal of International Law, 20/3: 615-645.

Firger, D. M., and Gerrard, M. (2012), 'Harmonizing Climate Change Policy and International Investment Law: Threats, Challenges and Opportunities', in K. P. Sauvant (ed.), Yearbook on International Investment Law and Policy 2010-2011 (New York, NY: Oxford University Press), 517-566.

Ganz, D. A., and Ala'i, P. (2016), 'Climate Change Innovation, Products and Services Under the GATT/WTO System', in J. D. Sarnoff (ed.), Research Handbook on Intellectual Property and Climate Change (Cheltenham, UK: Edward Elgar), 271-315.

Gehl Sampath, P., and Roffe, P. (2012), Unpacking the International Technology Transfer Debate: Fifty Years and Beyond, ICTSD, Working Paper < http://www.ictsd.org/downloads/2012/07/unpacking-the-international-technology-transfer-debate-fifty-years-and-beyond.pdf $>$.

Gehring, M. W., Cordonier Segger, M.-C., Andrade Correa, F. de et al. (2013), Climate Change and Sustainable Energy Measures in Regional Trade Agreements, ICTSD, Issue Paper, No. $3<\underline{\text { http:// }}$ www.ictsd.org/downloads/2013/08/climate-change-and-sustainable-energy-measures-in-regional-trade-agreements-rtas.pdf $>$.

Godard, O. (2007), Unilateral European Post-Kyoto Climate Policy and Economic Adjustment at EU Borders, École Polytechnique.

Herve, A., and Luff, D. (2012), Trade Law Implications of Procurement Practices in Sustainable Energy Goods and Services, ICTSD < http://mercury.ethz.ch/serviceengine/Files/ISN/154724/ ipublicationdocument_singledocument/a894ee2d-48a1-4d5e-a624-9cc0a9b53e35/en/trade-lawimplications-of-procurement-practices-in-sustainable-energy-goods-and-services.pdf $>$.

Holzer, K., and Cottier, T. (2015), 'Addressing Climate Change under Preferential Trade Agreements. Towards Alignment of Carbon Standards under the Transatlantic Trade and Investment Partnership', Global Environmental Change, 35: 514-522.

Horlick, G., and Clarke, P. A. (2016), Rethinking Subsidy Disciplines for the Future, E15 Initiative, Synthesis of the Policy Options, No. $18<$ http://e15initiative.org/wp-content/uploads/2015/09/ E15 no18 Subsidies final REV x1.pdf $>$.

Howse, R. (2013), Securing Policy Space for Clean Energy under the SCM Agreement: Alternative Approaches, E15 Initiative, Think Piece < $\underline{\text { http://e15initiative.org/wp-content/uploads/2015/09/ }}$ E15-CETs-Howse-Final.pdf>.

Howse, R., and Eliason, A. L. (2009), 'Domestic and International Strategies to Address Climate Change: an Overview of the WTO Legal Issues Change Debate', in T. Cottier, O. Nartova, and S. 
Z. Bigdeli (eds.), International Trade Regulation and the Mitigation of Climate Change. World Trade Forum (Cambridge: Cambridge University Press), 48-94.

Hufbauer, G. C., Charnovitz, S., and Jisun, K. (2009), Global Warming and the World Trading System (Washington, DC: Peterson Institute for International Economics).

ICTSD (2011a), Fostering Low Carbon Growth: The Case for a Sustainable energy Trade Agreement, ICTSD $<$ http://www.ictsd.org/downloads/2011/12/fostering-low-carbon-growth-the-casefor-a-sustainable-energy-trade-agreement.pdf $>$.

- (2011b), US Proclaims Victory in Wind Power Case; China Ends Challenged Subsidies, ICTSD, BRIDGES, Vol. 15 - No. $25<$ http://www.ictsd.org/bridges-news/bridges/news/us-proclaims-victory-in-wind-power-case-china-ends-challenged-subsidies $>$.

- (2012a), US Probe into China, Vietnam Wind Tower Imports Moves Forward, ICTSD, BRIDGES, Vol. 16 - No. $6<$ http://www.ictsd.org/bridges-news/bridges/news/us-probe-intochina-vietnam-wind-tower-imports-moves-forward>.

-(2012b), US-China Renewable Energy Row Escalates with Solar Duty Announcement, ICTSD, BRIDGES, Vol. 16 - No. 20 <http://www.ictsd.org/bridges-news/bridges/news/us-china-renewable-energy-row-escalates-with-solar-duty-announcement>.

- (2014), WTO Panel to Examine EU Duties on Argentine Biodiesel, ICTSD, BIORES, Vol. 18 - No. $15<$ http://www.ictsd.org/bridges-news/bridges/news/wto-panel-to-examine-eu-duties-onargentine-biodiesel $>$.

(2015), Overview of Outcomes of WTO's $10^{\text {th }}$ Ministerial in Nairobi, ICTSD, BRIDGES Daily Updates, No. $5<$ http://www.ictsd.org/bridges-news/bridges/news/bridges-daily-update-5-overview-of-outcomes-of-wto $\% \mathrm{E} 2 \% 80 \% 99 \mathrm{~s}$-10th-ministerial-in $>$.

_ (2016a), WTO Decision on Local Content Requirements Will Not Affect India Solar Ambitions, Officials Say, ICTSD, BIORES, Vol. 20 - No. $15<$ http://www.ictsd.org/bridges-news/bridges/ news/wto-decision-on-local-content-requirements-will-not-affect-india-solar>.

- (2016b), India Lodges WTO Appeal in US Solar Cells Dispute, ICTSD, BIORES, Vol. 20 No. $15<$ http://www.ictsd.org/bridges-news/bridges/news/india-lodges-wto-appeal-in-us-solarcells-dispute>.

- (2016c), EU, Argentina File Appeals in Biodiesel WTO Dispute, ICTSD, BRIDGES, Vol. 20

- No. $20<$ http://www.ictsd.org/bridges-news/bridges/news/eu-argentina-file-appeals-in-biodiesel-wto-dispute>.

IEA (2015), World Energy Outlook Special Report: Energy and Climate Change, IEA $<\underline{\text { https:// }}$ www.iea.org/publications/freepublications/publication/WEO2015SpecialReportonEnergyandClimateChange.pdf $>$.

International Bar Association (2014), Achieving Justice and Human Rights in an Era of Climate Change Disruption $<$ http://www.ibanet.org/Document/Default.aspx?DocumentUid=0F8CEE12EE56-4452-BF43-CFCAB196CC04>.

Ismer, R., and Neuhoff, K. (2007), 'Border Tax Adjustment. A Feasible Way to Support Stringent Emission Trading', European Journal of Law and Economics, 24/2: 137-164.

Jegou, I., Hawkins, S., and Botwright, K. (2016), What Role for Trade and Investment in the new Climate Regime?, ICTSD, BIORES, Vol. 10 - No. 1.

Jinnah, S., and Morgera, E. (2013), 'Environmental Provisions in American and EU Free Trade Agreements. A Preliminary Comparison and Research Agenda', Review of European, Comparative \& International Environmental Law, 22/3: 324-339.

Kennedy, M. (2012), Legal Options for a Sustainable Energy Trade Agreement, ICTSD $<$ http:// www.ictsd.org/downloads/2012/07/legal-options-for-a-sustainable-energy-trade-agreement.pdf $>$.

Keohane, N., Petsonk, A., and Hanafi, A. (2015), 'Toward a Club of Carbon Markets', Climatic Change, $2015<$ http://link.springer.com/article/10.1007/s10584-015-1506-z > . 
Koakutsu, K. (2016), 'Cooperative Implementation The Joint Crediting Mechanism (JCM) as an Example of Article 6.2 Activities', Carbon Mechanisms Review, 2016: 12-15 <http://www.carbon-mechanisms.de/fileadmin/media/dokumente/publikationen/CMR_2016_01_Dawning bf.pdf>.

Kortum, S., and Weisbach, D. (2016), Border Adjustments for Carbon Emissions: Basic Concepts and Design, Resources for the Future, Discussion Paper, 16-09.

Kreibich, N., and Obergassel, W. (2016), Carbon Markets After Paris: How to Account for the Transfer of Mitigation Results?, Wuppertal Institute for Climate, Environment and Energy, JIKO Policy Paper, No. 1.

Lall, S. (1993), 'Understanding Technology Development', Development and Change, 24/4: 719753.

Latif, A. A., Maskus, K., Okediji, R. et al. (2011), Overcoming the Impasse on Intellectual Property and Climate Change at the UNFCCC: A Way Forward, ICTSD, Policy Brief, No. $11<$ http:// www.ictsd.org/sites/default/files/research/2012/02/overcoming-the-impasse-on-intellectualproperty-and-climate-change-at-the-unfccc-a-way-forward.pdf $>$.

Leal-Arcas, R. (2012), 'Unilateral Trade-related Climate Change Measures', The Journal of World Investment \& Trade, 13/6: 875-927.

Lema, A., and Lema, R. (2013), 'Technology Transfer in the Clean Development Mechanism. Insights from Wind Power', Global Environmental Change, 23/1: 301-313.

Lewis, J. I. (2007), 'Technology Acquisition and Innovation in the Developing World. Wind Turbine Development in China and India', Studies in Comparative International Development, 42/34: $208-232$.

— (2014), 'The Rise of Renewable Energy Protectionism. Emerging Trade Conflicts and Implications for Low Carbon Development', Global Environmental Politics, 14/4: 10-35.

Leycegui, B., and Ramirez, I. (2015), Addressing Climate Change: A WTO Exception to Incorporate Climate Clubs, The E15 Initiative, Think Piece $<$ http://e15initiative.org/wp-content/uploads/ 2015/01/E15 Climate Leycegui-and-Ramirez FINAL.pdf>.

Marcu, A. (2016), Carbon Market Provisions in the Paris Agreement (Article 6), CEPS, CEPS Special Report, $\quad$ No. $128 \quad<$ http://www.ceps-ech.eu/sites/default/files/ SR\%20No\%20128\%20ACM\%20Post $\% 20$ COP $21 \% 20$ Analysis $\% 20$ of $\% 20$ Article $\% 206$.pdf $>$.

Martin, M. (2007), 'Trade Law Implications of Restricting Participation in the European Union Emissions Trading Scheme', The Georgetown International Environmental Law Review, 19/3: 437-474.

Maskus, K. E., and Okediji, R. L. (2010), Intellectual Property Rights and International Technology Transfer to Address Climate Change: Risks, Opportunities and Policy Options, ICTSD, Issue Paper, No. $32<$ http://www.ictsd.org/downloads/2011/12/intellectual-property-rights-and-international-technology-transfer-to-adress-climate-change.pdf $>$.

Meléndez-Ortiz, R. (2016), Enabling the Energy Transition and Scale-up of Clean Energy Technologies: Options for the Global Trade System, E15 Initiative, Policy Options Paper $<\underline{\mathrm{http}} / / / \mathrm{e} 15 \mathrm{ini}-$ tiative.org/wp-content/uploads/2015/09/E15 ICTSD Enabling_Energy Transition_Scale-Up Clean Energy Technologies report 2016 1002.pdf>.

Monkelbaan, J. (2013), Trade in Sustainable Energy Services, ICTSD $<$ http://www.ictsd.org/downloads/2013/10/trade-in-sustainble-energy-services.pdf>

Mowery, D. C., and Rosenberg, N. (1989), Technology and the Pursuit of Economic Growth (Cambridge: Cambridge University Press).

Munro, J. (2014), 'Trade in Carbon Units as a Financial Service under International Trade Law: Recent Developments, Future Challenges', Carbon \& Climate Law Review, 8/2: 106-114.

Nelson, R. R., and Winter, S. G. (1996), An Evolutionary Theory of Economic Change (Cambridge, MA: Belknap Press). 
Nordhaus, W. (2015), 'Climate Clubs. Overcoming Free-riding in International Climate Policy', American Economic Review, 105/4: 1339-1370.

Ockwell, D. G. (2008), Intellectual Property Rights and Low Carbon Technology Transfer to Developing Countries - a Review of the Evidence to Date, Sussex Energy Group, The Energy and Resources Institute, Institute of Development Studies $<$ https://www.sussex.ac.uk/webteam/gateway/file.php?name=spru-teri-ids-phase-2-iprs-and-low-c-tt-final.pdf\&site=264>.

Ockwell, D. G., Haum, R., Mallett, A. et al. (2010), 'Intellectual Property Rights and Low Carbon Technology Transfer. Conflicting Discourses of Diffusion and Development', Global Environmental Change, 20/4: 729-738.

Palmeter, D. (2000), 'The WTO as a Legal System', Fordham International Law Journal, 24/1: 444-480.

Panagariya, A. (2002), Core WTO Agreements: Trade in Goods and Services and Intellectual Property, Columbia University $<$ http://www.columbia.edu/ ap2231/Courses/wto-overview.pdf $>$.

Pauwelyn, J. (2007), U.S. Federal Climate Policy and Competitiveness Concerns: The Limits and Options of International Trade Law, Nicholas Institute for Environmental Policy Solutions, Working Paper, 07-02 <https://nicholasinstitute.duke.edu/sites/default/files/publications/u.s.-federal-climate-policy-and-competitiveness-concerns-the-limits-and-options-of-international-tradelaw-paper.pdf> .

- (2013), 'Carbon Leakage Measures and Border Tax Adjustments under WTO Law', in D. Prevost and G. v. Calster (eds.), Research Handbook on Environment, Health and the WTO (Research handbook on the WTO, Cheltenham: Edward Elgar), 448-506.

Petsonk, A. (1999), 'The Kyoto Protocol and the WTO: Integrating Greenhouse Gas Emissions Allowance Trading into the Global Marketplace', Duke Environmental Law \& Policy Forum, 10/1: $185-220$.

Phillips, J., Das, K., and Newell, P. (2013), 'Governance and Technology Transfer in the Clean Development Mechanism in India', Global Environmental Change, 23/6: 1594-1604.

Piera, A. (2016), 'Compliance Tools for a Global Market Based Measure for Aviation. Designing the Legal Form of a Global Aviation Market Based Measure', Carbon \& Climate Law Review, 10/2: 144-152.

Shedd, D. T., Murrill, B. J., and Smith, J. M. (2012), Dispute Settlement in the World Trade Organization (WTO): An Overview, Congressional Research Service, CRS Report for Congress $<$ https:// www.fas.org/sgp/crs/misc/RS20088.pdf>.

Steenblik, R., and Simón, J. (2011), A New Template for Notifying Subsidies to the WTO, IISD $<$ http://www.globalsubsidies.org/files/assets/template_for_notifying_subsidies_to the WTO.pdf $>$.

Steiner, M. (2015), The WTO Government Procurement Agreement: Assessing the Scope for Green Procurement, ICTSD, BIORES, Vol. 9 - No. $10<$ http://www.ictsd.org/bridges-news/biores/ news/the-wto-government-procurement-agreement-assessing-the-scope-for-green>.

Sugathan, M. (2015), Addressing Energy Efficiency Products in the Environmental Goods Agreement, ICTSD, Issue Paper, No. $20<$ http://www.ictsd.org/sites/default/files/research/Addressing $\% 20$ Energy $\% 20$ Efficiency $\% 20$ Products $\% 20$ in $\% 20$ the $\% 20$ Environmen-

tal $\% 20$ Goods $\% 20$ Agreement $\% 20$ Issues, $\% 20$ Challenges $\% 20$ and $\% 20$ the $\% 20$ Way $\% 20$ Forward.pdf $>$.

Tamiotti, L. (2011), 'The Legal Interface between Carbon Border Measures and Trade Rules', Climate Policy, 11/5: 1202-1211.

Tamiotti, L., Teh, R., Kulaçoğlu, V. et al. (2009), Trade and Climate Change: A Report by the United Nations Environment Programme and the World Trade Organization (Geneva: World Trade Organization and United Nations Environment Programme). 
The Times of India (2016), India Drags US to WTO over Renewable Energy, 12.09.2016 <http:// timesofindia.indiatimes.com/home/environment/developmental-issues/India-drags-US-to-WTOover-renewable-energy/articleshow/54295541.cms $>$.

UNFCCC (1992), United Nations Framework Convention on Climate Change $<$ https://unfccc.int/ resource/docs/convkp/conveng.pdf>

- (2011), Decision 1/CP.16< <http://unfccc.int/resource/docs/2010/cop16/eng/07a01.pdf?.

— (2015a), Decision 11/CP.21<http://unfccc.int/resource/docs/2015/cop21/eng/10a02.pdf $>$. (2015b), Paris Agreement $<$ https://unfccc.int/resource/docs/2015/cop21/eng/109.pdf $>$.

(2016), Guidance to Assist Developing Country Parties to Assess the Impact of the Implementation of Response Measures, including Guidance on Modelling Tools $<$ http://unfccc.int/resource/ docs $/ 2016 / \mathrm{tp} / 04 . p d f>$.

van Asselt, H. (2014a), The Fragmentation of Global Climate Governance: Consequences and Management of Regime Interactions (Cheltenham: Edward Elgar).

- (2014b), Governing the Transition Away from Fossil Fuels: The Role of International Institutions, Stockholm Environment Institute, Stockholm Environment Institute Working Paper, 2014$07<$ https://www.sei-international.org/mediamanager/documents/Publications/Climate/SEI-WP2014-07-Fossil-fuels-intl-institutions.pdf $>$.

van Asselt, H., and Brewer, T. (2010), 'Addressing Competitiveness and Leakage Concerns in Climate Policy. An Analysis of Border Adjustment Measures in the US and the EU', Energy Policy, 38/1: 42-51.

van Asselt, H., Sindico, F., and Mehling, M. A. (2008), 'Global Climate Change and the Fragmentation of International Law', Law \& Policy, 30/4: 423-449.

Voigt, C. (2008), 'WTO Law and International Emissions Trading: Is there Potential for Conflict?', Carbon and Climate Law Review, 1/2: 54-66.

Werksman, J. (1999), 'Greenhouse Gas Emissions Trading and the WTO', Review of European Community and International Environmental Law, 8/3: 251-264.

Wiser, G. M. (1999), 'The Clean Development Mechanism Versus the World Trade Organization: Can Free-market Greenhouse Gas Emissions Abatement survive Free Trade?', Georgetown Environmental Law Review, 11/3: 531-598.

Wold, C., Wilson, G., and Foroshani, S. (2012), 'Leveraging Climate Change Benefits through the World Trade Organization: Are Fossil Fuel Subsidies Actionable?', Georgetown Journal of International Law, 43/3: 587-633.

World Bank (2008), Global Economic Prospects: Technology Diffusion in the Developing World $<$ http://siteresources.worldbank.org/INTGEP2008/Resources/complete-report.pdf $>$.

World Economic Forum (2014), Mega-regional Trade Agreements: Game-Changers or Costly Distractions for the World Trading System? < http://www3.weforum.org/docs/GAC/2014/WEF GAC TradeFDI_MegaRegionalTradeAgreements_Report_2014.pdf $>$.

WTO (1995), Agreement on Establishing the WTO $<$ https://www.wto.org/english/docs e/legal_e/ 04-wto.pdf>.

- (2010), The WTO TRIPS Agreement - A Practical Overview for Climate Change Policy Makers $<$ https://www.wto.org/english/tratop_e/trips_e/trips_and_climate_paper_e.pdf $>$.

- (2011), Environmental Services - Overview of Classification Issues, Informal Note by the Secretariat, JOB/SERV/84 <https://www.google.de/

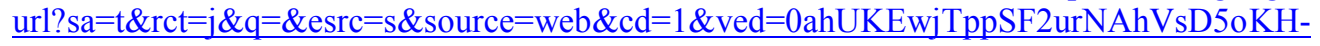
cLCDXIQFgggMAA\&url=http\%3A\%2F\%2Fwww.een.kso.org.tr\%2Fup \%2Fdene\%2FDUY 04092011\%28DTO\%29 Anlasmasi\%28GATS\%29.pdf\&usg=AFQjCNHKGrJ4n3alV39opmz05d08EL577A\&cad=rja $>$.

- (2014), Technical Barriers to Trade, The WTO Agreement Series $<\underline{\mathrm{https}} / / \mathrm{www}$.wto.org/eng$\underline{\text { lish/res_e/publications_e/tbttotrade_e.pdf }>}$. 
Yu, P. K. (2016), 'Intellectual Property Enforcement and Global Climate Change', in J. D. Sarnoff (ed.), Research Handbook on Intellectual Property and Climate Change (Cheltenham: Edward Elgar), 107-125. 
ANNEX: Climate-RELATEd WTO DisPUTES

\begin{tabular}{|c|c|c|c|c|c|c|c|c|}
\hline $\begin{array}{l}\text { Dis- } \\
\text { pute } \\
\text { number }\end{array}$ & Dispute title $^{1}$ & $\begin{array}{l}\text { Respond- } \\
\text { ent }\end{array}$ & $\begin{array}{l}\text { Complain- } \\
\text { ant }\end{array}$ & Third parties ${ }^{2}$ & $\begin{array}{l}\text { Challenged } \\
\text { measure(s) }\end{array}$ & $\begin{array}{l}\text { Agreements } \\
\text { cited (in the } \\
\text { request for } \\
\text { consulta- } \\
\text { tions) }\end{array}$ & $\begin{array}{l}\text { Date of initi- } \\
\text { ation (re- } \\
\text { quest for } \\
\text { consulta- } \\
\text { tions) }\end{array}$ & Current status \\
\hline DS412 & $\begin{array}{l}\text { Canada - Certain } \\
\text { Measures Affecting } \\
\text { the Renewable En- } \\
\text { ergy Generation } \\
\text { Sector (Canada - } \\
\text { Renewable En- } \\
\text { ergy) }\end{array}$ & Canada & Japan & $\begin{array}{l}\text { Australia; Bra- } \\
\text { zil; China; Chi- } \\
\text { nese Taipei; El } \\
\text { Salvador; EU; } \\
\text { Honduras; In- } \\
\text { dia; Mexico; } \\
\text { Norway; Saudi } \\
\text { Arabia; South } \\
\text { Korea; US }\end{array}$ & $\begin{array}{l}\text { Ontario's feed-in } \\
\text { tariff program } \\
\text { with LCRs for } \\
\text { electricity gener- } \\
\text { ation using solar } \\
\text { photovoltaic and } \\
\text { wind power tech- } \\
\text { nology. }\end{array}$ & $\begin{array}{l}\text { GATT; SCM } \\
\text { Agreement; } \\
\text { TRIMS } \\
\text { Agreement }\end{array}$ & $\begin{array}{l}\text { 13 Septem- } \\
\text { ber } 2010\end{array}$ & $\begin{array}{l}\text { On } 5 \text { June } 2014 \text {, the respondent } \\
\text { (Canada) notified that it "imple- } \\
\text { mented" the DSB recommenda- } \\
\text { tion to bring the disputed meas- } \\
\text { ure into conformity with WTO } \\
\text { law. No compliance proceeding } \\
\text { initiated. }\end{array}$ \\
\hline$\underline{\text { DS419 }}$ & $\begin{array}{l}\text { China - Measures } \\
\text { Concerning Wind } \\
\text { Power } \\
\text { Equipment }\end{array}$ & China & US & None & $\begin{array}{l}\text { China's grants, } \\
\text { funds, or awards } \\
\text { to enterprises } \\
\text { manufacturing } \\
\text { wind power } \\
\text { equipment con- } \\
\text { tingent on local } \\
\text { content require- } \\
\text { ments. }\end{array}$ & $\begin{array}{l}\text { GATT; SCM } \\
\text { Agreement; } \\
\text { China-Proto- } \\
\text { col of Acces- } \\
\text { sion }\end{array}$ & $\begin{array}{l}22 \text { December } \\
2010\end{array}$ & $\begin{array}{l}\text { On } 22 \text { December } 2010 \text {, the com- } \\
\text { plainant (US) requested consul- } \\
\text { tations with the respondent } \\
\text { (China). No dispute panel estab- } \\
\text { lished and no withdrawal or mu- } \\
\text { tually agreed solution notified. }\end{array}$ \\
\hline
\end{tabular}




\begin{tabular}{|c|c|c|c|c|c|c|c|c|}
\hline$\underline{\mathrm{DS} 426}$ & $\begin{array}{l}\text { Canada- } \\
\text { Measures Relating } \\
\text { to the Feed-in Tariff } \\
\text { Program (Canada } \\
\text { - Feed-In Tariff } \\
\text { Program) }\end{array}$ & Canada & EU & $\begin{array}{l}\text { Australia; Bra- } \\
\text { zil; China; Chi- } \\
\text { nese Taipei; El } \\
\text { Salvador; In- } \\
\text { dia; Japan; Me- } \\
\text { xico; Norway; } \\
\text { Saudi Arabia; } \\
\text { South Korea; } \\
\text { Turkey; US; El } \\
\text { Salvador }\end{array}$ & $\begin{array}{l}\text { Ontario's feed-in } \\
\text { tariff programme } \\
\text { with local con- } \\
\text { tent requirement } \\
\text { for electricity } \\
\text { generation using } \\
\text { solar photovol- } \\
\text { taic and wind } \\
\text { power technol- } \\
\text { ogy. }\end{array}$ & $\begin{array}{l}\text { GATT; SCM } \\
\text { Agreement; } \\
\text { TRIMS } \\
\text { Agreement }\end{array}$ & $\begin{array}{l}11 \text { August } \\
2011\end{array}$ & $\begin{array}{l}\text { On } 5 \text { June } 2014 \text {, the respondent } \\
\text { (Canada) notified that it "imple- } \\
\text { mented" the DSB recommenda- } \\
\text { tion to bring the disputed meas- } \\
\text { ure into conformity with WTO } \\
\text { law. No compliance proceeding } \\
\text { initiated. }\end{array}$ \\
\hline DS437 & $\begin{array}{l}\text { United States - } \\
\text { Countervailing } \\
\text { Duty Measures on } \\
\text { Certain Products } \\
\text { from China (US - } \\
\text { Countervailing } \\
\text { Measures (China)) }\end{array}$ & US & China & $\begin{array}{l}\text { Australia; Bra- } \\
\text { zil; Canada; } \\
\text { EU; India; Ja- } \\
\text { pan; Norway; } \\
\text { Russian Feder- } \\
\text { ation; Saudi } \\
\text { Arabia; South } \\
\text { Korea; Turkey; } \\
\text { Vietnam }\end{array}$ & $\begin{array}{l}17 \text { CVD investi- } \\
\text { gations con- } \\
\text { ducted by the US } \\
\text { against various } \\
\text { Chinese prod- } \\
\text { ucts, which in- } \\
\text { cluded solar pan- } \\
\text { els and wind } \\
\text { towers. }\end{array}$ & $\begin{array}{l}\text { SCM Agree- } \\
\text { ment; } \\
\text { GATT; } \\
\text { China-Proto- } \\
\text { col of Acces- } \\
\text { sion }\end{array}$ & 25 May 2012 & $\begin{array}{l}\text { AB and/or panel found the dis- } \\
\text { puted measure(s) to be incon- } \\
\text { sistent with WTO law. Report(s) } \\
\text { adopted by the DSB on } 16 \text { Janu- } \\
\text { ary } 2015 \text {, with recommendations } \\
\text { to bring the US measure(s) into } \\
\text { conformity with WTO law. The } \\
\text { US is undertaking implementa- } \\
\text { tion of these recommendations. } \\
\text { In January } 2016 \text {, the US and } \\
\text { China reached a procedural un- } \\
\text { derstanding regarding possible } \\
\text { further proceedings to facilitate } \\
\text { the resolution of the dispute. }\end{array}$ \\
\hline$\underline{\mathrm{DS} 443}$ & $\begin{array}{l}\text { European Union } \\
\text { and a Member State } \\
\text { - Certain Measures } \\
\text { Concerning the Im- } \\
\text { portation of Bio- } \\
\text { diesels }\end{array}$ & EU; Spain & Argentina & None & $\begin{array}{l}\text { Spanish Ministe- } \\
\text { rial Order regu- } \\
\text { lating allocation } \\
\text { of quantities of } \\
\text { biodiesel needed } \\
\text { to achieve the } \\
\text { mandatory target }\end{array}$ & $\begin{array}{l}\text { GATT; } \\
\text { TRIMS } \\
\text { Agreement; } \\
\text { Agreement } \\
\text { Establishing } \\
\text { the WTO }\end{array}$ & $\begin{array}{l}17 \text { August } \\
2012\end{array}$ & $\begin{array}{l}\text { On } 17 \text { August 2012, the com- } \\
\text { plainant (Argentina) requested } \\
\text { consultations with the Respond- } \\
\text { ent (EU; Spain). No dispute } \\
\text { panel established and no with- } \\
\text { drawal or mutually agreed solu- } \\
\text { tion notified. }\end{array}$ \\
\hline
\end{tabular}




\begin{tabular}{|c|c|c|c|c|c|c|c|c|}
\hline & & & & & $\begin{array}{l}\text { of renewable en- } \\
\text { ergy. The meas- } \\
\text { ure is the na- } \\
\text { tional implemen- } \\
\text { tation of the EU } \\
\text { regulatory frame- } \\
\text { work for renewa- } \\
\text { ble energy. }\end{array}$ & & & \\
\hline$\underline{\mathrm{DS} 452}$ & $\begin{array}{l}\text { European Union } \\
\text { and Certain Mem- } \\
\text { ber States - Certain } \\
\text { Measures Affecting } \\
\text { the Renewable En- } \\
\text { ergy Generation } \\
\text { Sector }\end{array}$ & $\begin{array}{l}\text { EU; Italy; } \\
\text { Greece }\end{array}$ & China & None & $\begin{array}{l}\text { Feed-in tariff } \\
\text { programs with } \\
\text { local content re- } \\
\text { quirements in EU } \\
\text { Member States, } \\
\text { including but not } \\
\text { limited to Italy } \\
\text { and Greece. }\end{array}$ & $\begin{array}{l}\text { GATT 1994; } \\
\text { ASCM; } \\
\text { TRIMs }\end{array}$ & $\begin{array}{l}5 \text { November } \\
2012\end{array}$ & $\begin{array}{l}\text { On } 5 \text { November } 2012 \text {, the com- } \\
\text { plainant (China) requested con- } \\
\text { sultations with the respondent } \\
\text { (EU; Italy; Greece). No dispute } \\
\text { panel established and no with- } \\
\text { drawal or mutually agreed solu- } \\
\text { tion notified. }{ }^{9}\end{array}$ \\
\hline$\underline{\mathrm{DS} 456}$ & $\begin{array}{l}\text { India-Certain } \\
\text { Measures Relating } \\
\text { to Solar Cells and } \\
\text { Solar Modules (In- } \\
\text { dia - Solar Cells) }\end{array}$ & India & US & $\begin{array}{l}\text { Brazil; Canada; } \\
\text { China; Chinese } \\
\text { Taipei; Ecua- } \\
\text { dor; EU; Japan; } \\
\text { Malaysia; Nor- } \\
\text { way; Russian } \\
\text { Federation; } \\
\text { Saudi Arabia; } \\
\text { South Korea; } \\
\text { Turkey }\end{array}$ & $\begin{array}{l}\text { LCRs pertaining } \\
\text { to solar cells } \\
\text { and/or modules } \\
\text { imposed by India } \\
\text { in the initial } \\
\text { phases of India's } \\
\text { ongoing National } \\
\text { Solar Mission, } \\
\text { related to solar } \\
\text { power develop- } \\
\text { ers selling elec- } \\
\text { tricity to the gov- } \\
\text { ernment. }\end{array}$ & $\begin{array}{l}\text { GATT; SCM } \\
\text { Agreement; } \\
\text { TRIMS } \\
\text { Agreement }\end{array}$ & $\begin{array}{l}6 \text { February } \\
2013\end{array}$ & $\begin{array}{l}\text { The case went up to AB stage } \\
\text { following appeal of the panel re- } \\
\text { port by India on } 20 \text { April } 2016 \text {. } \\
\text { On } 16 \text { September } 2016 \text {, the AB } \\
\text { ruled against India. }{ }^{10}\end{array}$ \\
\hline
\end{tabular}




\begin{tabular}{|c|c|c|c|c|c|c|c|c|}
\hline DS459 & $\begin{array}{l}\text { European Union } \\
\text { and Certain Mem- } \\
\text { ber States - Certain } \\
\text { Measures on the } \\
\text { Importation and } \\
\text { Marketing of Bio- } \\
\text { diesel and Measures } \\
\text { Supporting the Bio- } \\
\text { diesel Industry }\end{array}$ & EU & Argentina & None & $\begin{array}{l}\text { Measures to pro- } \\
\text { mote the use of } \\
\text { energy from re- } \\
\text { newable sources, } \\
\text { and measures to } \\
\text { establish support } \\
\text { schemes for the } \\
\text { biodiesel sector. }\end{array}$ & $\begin{array}{l}\text { GATT; TBT } \\
\text { Agreement; } \\
\text { Agreement } \\
\text { Establishing } \\
\text { the WTO; } \\
\text { TRIMS } \\
\text { Agreement; } \\
\text { SCM Agree- } \\
\text { ment }\end{array}$ & 15 May 2013 & $\begin{array}{l}\text { On } 15 \text { May 2013, the complain- } \\
\text { ant (Argentina) requested con- } \\
\text { sultations with the respondent } \\
\text { (EU). No dispute panel estab- } \\
\text { lished and no withdrawal or mu- } \\
\text { tually agreed solution notified. }{ }^{11}\end{array}$ \\
\hline DS473 & $\begin{array}{l}\text { European Union - } \\
\text { Anti-Dumping } \\
\text { Measures on Bio- } \\
\text { diesel from Argen- } \\
\text { tina (EU - Bio- } \\
\text { diesel) }\end{array}$ & EU & Argentina & $\begin{array}{l}\text { Australia; } \\
\text { China; Colom- } \\
\text { bia; Indonesia; } \\
\text { Malaysia; Mex- } \\
\text { ico; Norway; } \\
\text { Russian Feder- } \\
\text { ation; Saudi } \\
\text { Arabia; Tur- } \\
\text { key; US }\end{array}$ & $\begin{array}{l}\text { Anti-dumping } \\
\text { measures im- } \\
\text { posed by the EU } \\
\text { in } 2013 \text { on bio- } \\
\text { diesel originating } \\
\text { in, inter alia, Ar- } \\
\text { gentina; and cer- } \\
\text { tain provisions in } \\
\text { the EU regula- } \\
\text { tion regarding } \\
\text { determination of } \\
\text { dumping mar- } \\
\text { gins. }\end{array}$ & $\begin{array}{l}\text { Anti-Dump- } \\
\text { ing Agree- } \\
\text { ment; } \\
\text { GATT; } \\
\text { Agreement } \\
\text { Establishing } \\
\text { the WTO }\end{array}$ & $\begin{array}{l}19 \text { December } \\
2013\end{array}$ & $\begin{array}{l}\text { On } 29 \text { March } 2016 \text {, the panel re- } \\
\text { port was circulated to members. } \\
\text { Not yet adopted or appealed. }{ }^{12}\end{array}$ \\
\hline DS480 & $\begin{array}{l}\text { European Union-- } \\
\text { Anti-Dumping } \\
\text { Measures on Bio- } \\
\text { diesel from Indone- } \\
\text { sia (EU - Bio- } \\
\text { diesel (Indonesia)) }\end{array}$ & EU & Indonesia & $\begin{array}{l}\text { Argentina; } \\
\text { Australia; Bra- } \\
\text { zil; Canada; } \\
\text { China; India; } \\
\text { Japan; Norway; } \\
\text { Russian Feder- } \\
\text { ation; Singa- } \\
\text { pore; Turkey; } \\
\text { Ukraine; US }\end{array}$ & $\begin{array}{l}\text { Certain provi- } \\
\text { sions in EU regu- } \\
\text { lation on Anti- } \\
\text { dumping from } \\
\text { non-EU coun- } \\
\text { tries; and anti- } \\
\text { dumping } \\
\text { measures im- } \\
\text { posed in } 2013 \text { by }\end{array}$ & $\begin{array}{l}\text { Anti-Dump- } \\
\text { ing Agree- } \\
\text { ment; Agree- } \\
\text { ment Estab- } \\
\text { lishing the } \\
\text { WTO; } \\
\text { GATT }\end{array}$ & 10 June 2014 & $\begin{array}{l}\text { At its meeting on } 31 \text { August } \\
2015 \text {, the DSB established a } \\
\text { panel. Following the agreement } \\
\text { of the parties, the panel was } \\
\text { composed on } 4 \text { November } \\
2015.13\end{array}$ \\
\hline
\end{tabular}




\begin{tabular}{|c|c|c|c|c|c|c|c|c|}
\hline & & & & & $\begin{array}{l}\text { the EU on im- } \\
\text { ports of biodiesel } \\
\text { originating in, in- } \\
\text { ter alia, Indone- } \\
\text { sia. }\end{array}$ & & & \\
\hline$\underline{\mathrm{DS} 510}$ & $\begin{array}{l}\text { United States - Cer- } \\
\text { tain Measures Re- } \\
\text { lating to the Renew- } \\
\text { able Energy Sector }\end{array}$ & US & India & Not yet known & $\begin{array}{l}\text { Domestic content } \\
\text { requirements and } \\
\text { subsidies pro- } \\
\text { vided by eight } \\
\text { US states (Wash- } \\
\text { ington, Califor- } \\
\text { nia, Montana, } \\
\text { Massachusetts, } \\
\text { Connecticut, } \\
\text { Michigan, Dela- } \\
\text { ware and Minne- } \\
\text { sota) in the re- } \\
\text { newable energy } \\
\text { sector. }\end{array}$ & $\begin{array}{l}\text { GATT; } \\
\text { TRIMS } \\
\text { Agreement; } \\
\text { SCM Agree- } \\
\text { ment; Agree- } \\
\text { ment Estab- } \\
\text { lishing the } \\
\text { WTO }\end{array}$ & $\begin{array}{l}\text { 9 September } \\
2016\end{array}$ & $\begin{array}{l}\text { Request for consultation by In- } \\
\text { dia. }{ }^{14}\end{array}$ \\
\hline \multicolumn{9}{|c|}{$\begin{array}{l}\text { Source: Kasturi Das, Technology Transfer under the Clean Development Mechanism: an Empirical Study of } 1000 \text { CDM Projects, https://pa- } \\
\text { pers.ssrn.com/sol3/papers2.cfm?abstract } \mathrm{id}=1887727 .\end{array}$} \\
\hline \multicolumn{9}{|c|}{$\begin{array}{l}\text { Notes: } \\
\text { 1. Short title of the dispute, wherever available, is given within open brackets. } \\
\text { 2. Any WTO member - other than the complainant and the respondent - can declare that it has an interest in the case and enjoy some rights as a "third party", } \\
\text { including participation in the proceedings, submission of written and oral testimony before the panel, etc. } \\
\text { 3. Susanne Droege, Harro van Asselt, Kasturi Das and Michael Mehling The Trade System and Climate Action: Ways Forward under the Paris Agreement, S.C. } \\
\text { J. INT'L. L. \& BUS. 14, } 20 . \\
\text { 4. Id. } \\
\text { 5. Panel and Appellate Body reports in Canada - Renewable Energy (DS412) and Canada - Feed-In Tariff Program (DS426) were released together (effec- } \\
\text { tively merging the two cases). }\end{array}$} \\
\hline
\end{tabular}


6. Droege, supra note 3, at 20.

7. Id.

8. Id. at 22 .

9. Id. at 21

10. Id at 21 .

11. Id. at 22 .

12. Id. at 22 .

13. Id. at 22 .

14. Id. at 22. 